ISSN (print): 1698-6180. ISSN (online): 1886-7995

www.ucm.es/info/estratig/journal.htm

Journal of Iberian Geology 36 (2) 2010: 275-296

doi:10.5209/rev_JIGE.2010.v36.n2.12

\title{
The evolution of large-bodied theropod dinosaurs during the Mesozoic in Asia
}

\author{
La evolución de los grandes dinosaurios terópodos durante el \\ Mesozoico de Asia
}

\author{
S. L. Brusatte ${ }^{1,2}$, R. B. J. Benson ${ }^{3}, X . \mathrm{Xu}^{4}$ \\ ${ }^{1}$ Division of Paleontology, American Museum of Natural History, Central Park West at 79th Street, New York, NY 10025, \\ USA.E-mail: sbrusatte@amnh.org \\ ${ }^{2}$ Department of Earth and Environmental Sciences, Columbia University, New York, NY, USA \\ ${ }^{3}$ Department of Earth Sciences, University of Cambridge, Downing Street, Cambridge, CB2 3EQ, United Kingdom. \\ E-mail:rbb27@cam.ac.uk \\ ${ }^{4}$ Institute of Vertebrate Paleontology and Paleoanthropology, Chinese Academy of Sciences, 142 Xiwai Street, Beijing \\ 100044, People’s Republic of China.E-mail:xingxu@vip.sina.com
}

Received: 06/11/09 / Accepted: 30/06/10

\begin{abstract}
The fossil record of large-bodied, apex carnivorous theropod dinosaurs in Eastern Asia is now among the best understood in the world, thanks to new discoveries and reinterpretations of long-neglected fossils. Asia boasts the most complete record of Middle Jurassic theropods globally, as well as one of the best-studied Late Cretaceous theropod faunas, and new research is helping to fill what was previously a 60-million-year gap in the Early-mid Cretaceous fossil record of large Asian predators. In general, the biogeographic affinities of large-bodied Asian theropods over time were intimately related to physical geography, and progressively more derived theropod clades evolved large body size and occupied the apex predator niche throughout the Jurassic and Cretaceous. During the Middle Jurassic, largely endemic clades of basal tetanurans were prevalent in Asia, whereas during the Late Jurassic-mid Cretaceous more derived "intermediate" tetanuran theropods with cosmopolitan affinities occupied the large predator role, including sinraptorids, spinosaurids, and carcharodontosaurians. Finally, during the final 20 million years of the Cretaceous, more derived, bird-like coelurosaurs attained large body size. Foremost among these were the tyrannosaurids, a radiation of northern (Asian and North American) megapredators whose ascent into the apex predator niche was a delayed event restricted to the Campanian-Maastrichtian. As Asia is the focus of intense ongoing dinosaur fieldwork, our understanding of large-bodied theropod evolution will continue to be refined with future discoveries.
\end{abstract}

Keywords: Asia, Dinosauria, Mesozoic, paleobiogeography, Theropoda, Tyrannosauridae. 


\section{Resumen}

El registro fósil de los dinosaurios carnívoros terópodos de gran talla en el este de Asia es uno de los mejor conocidos del mundo, gracias a nuevos descubrimientos y reinterpretaciones de fósiles que han permanecido pobremente estudiados durante mucho tiempo. Globalmente, Asia comprende el registro fósil más completo de terópodos del Jurásico Medio, así como una de las faunas finicretácicas mejor estudiadas. Asimismo, las nuevas investigaciones están contribuyendo a completar un hiato de 60 millones de años en el registro fósil de grandes depredadores asiáticos correspondientes al Cretácido inferior-medio. En general, las afinidades biogeográficas de los grandes terópodos asiáticos a través del tiempo se hallan intimamente ligadas a la geografía física. Progresivamente, varios clados derivados de terópodos evolucionaron grandes tallas corporales, ocupando la cima del nicho de depredador durante todo el Jurásico y el Cretácico. Durante el Jurásico Medio prevalecieron clados de tetanuros basales mayormente endémicos, mientras que durante el Jurásico Superior-Cretácico Medio clados más derivados de terópodos tetanuros "intermedios" de afinidades cosmopolitas ocuparon el papel de gran depredador, incluyendo sinraptóridos, espinosáuridos y carcharodontosáuridos. Finalmente, durante los últimos 20 millones de años del Cretácico, coelurosaurios más derivados con aspecto reminiscente a las aves alcanzaron grandes tallas corporales. Pirmordialmente entre estas formas se hallaban los tiranosáuridos, una radiación septentrional (asiáticos y norteamericanos) de megadepredadores cuyo ascenso a la cumbre del nicho de gran depredador se retrasó hasta el Campaniense y Maastrichtiense. Mientras Asia continúa constituyendo el foco de una intensa actividad paleontológica, nuestros conocientos sobre la evolución de los grandes terópoodos continuará refinándose con el estudio de futuros hallazgos.

Palabras clave: Asia, Dinosauria, Mesozoico, paleobiogeografía, Theropoda, Tyrannosauridae.

\section{Introduction}

Long overshadowed by discoveries in North America and Europe, the fossil record of Eastern Asian dinosaurs is now among the best documented in the world. Over the past two decades Asia has emerged as an epicenter of vertebrate paleontology research, thanks to the discovery of spectacular fossil sites in China (e.g., Zhou et al., 2003; Xu and Norell, 2006; Varricchio et al., 2008; Xu et al., 2009a,b) and Mongolia (e.g., Dashzeveg et al., 1995; Loope et al., 1998), as well as important new fossils from Japan (e.g., Azuma and Currie, 2000; Kobayashi and Azuma, 2003; Ohashi and Barrett, 2009) and Thailand (e.g., Buffetaut and Suteethorn, 1999). On average, a new Asian dinosaur is described once every two or three weeks, and many of these discoveries have graced the pages of high-impact journals and have been trumpeted in the popular press.

The most familiar and celebrated Asian dinosaurs are the "feathered dinosaurs" of the Jehol Biota, a remarkable assemblage of Early Cretaceous (ca. 125 million year old) carnivorous dinosaurs covered in various types of feathery integument (Ji et al., 1998; Norell and Xu, 2005; Xu and Norell, 2006). Although it was suggested that birds have some relationship with carnivorous theropod dinosaurs as early as the $19^{\text {th }}$ century (e.g., Huxley, 1868), and subsequently proposed that birds were the extant descendants of theropods (e.g., Ostrom, 1969), the discovery of the Jehol fossils in the mid 1990s provided the final, and most visual, piece of evidence: bona fide theropods with feathers. Today, the Jehol fossils, along with specimens from other sites in China such as the Middle-Late Jurassic Daohugou and Yanliao Faunas (e.g., Xu and Zhang, 2005; Zhang et al., 2008), continue to play key roles in debates over the timing of bird origins (e.g., Chen et al., 1998; Hu et al., 2009), the evolution of avian flight (e.g., Xu et al., 2003), the development of feathers (e.g., Prum and Brush, 2002; Xu et al., 2009c; Zheng et al., 2009), and the evolution of the unique avian hand (Xu et al., 2009a).

The feathered theropods of the Jehol Biota are among the best studied carnivorous dinosaurs in the world, but they all represent small-bodied theropods (most are smaller than an average-sized man). Considerably less is known about the large-bodied theropods of Asia: the apex predators in most Mesozoic terrestrial ecosystems, some of which reached lengths of $10+$ meters and masses of more than one tonne (Fig. 1). Comparatively few specimens of large, apex predator theropods are known from Asia, and there are substantial gaps in the fossil record of these carnivores. However, Asia does boast one of the most complete records of Middle Jurassic and Late Cretaceous large theropods from anywhere in the world, and recent discoveries and redescriptions are beginning to reveal long enigmatic details of large theropod evolution during the Late Jurassic-mid Cretaceous of Asia (e.g., Gao, 1999; Azuma and Currie, 2000; Benson and $\mathrm{Xu}, 2008$; Brusatte et al., 2009a; Brusatte et al. 2010b; Benson et al., 2010). In this paper, a companion to our presentation at the $10^{\text {th }}$ Mesozoic Terrestrial Ecosystems Symposium in Teruel, we provide an overview of largebodied theropod evolution during the Mesozoic in Eastern Asia, with a particular emphasis on new specimens and information. We focus on the body fossil record, and particularly on the most complete and best preserved specimens (Fig. 2). We do not cover all Asian theropods 


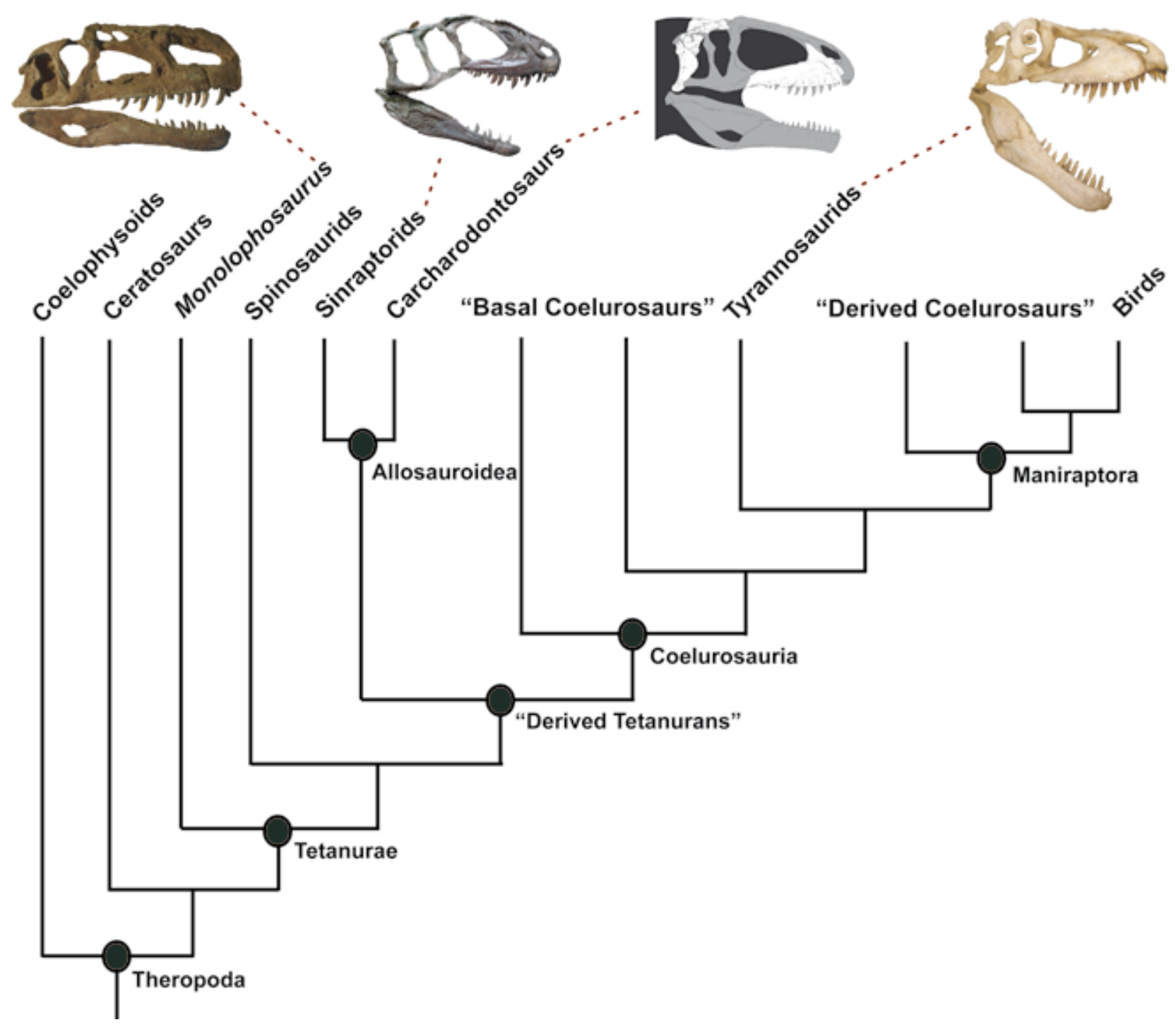

Fig. 1.-A framework phylogeny (genealogical tree) of theropod dinosaurs, with skull images of the most important groups of large carnivores from Asia. Basal theropods such as Monolophosaurus, belonging to endemic clades, filled the large carnivore niche in the Middle Jurassic, whereas allosauroid sinraptorids and carcharodontosaurians were the apex predators in the Late Jurassic and Early-mid Cretaceous of Asia, respectively. During the final 20 million years of the Cretaceous, more derived coelurosaurian theropods achieved large body size, most notably tyrannosaurids such as Tarbosaurus. Note that some analyses have recovered Monolophosaurus as a basal megalosauroid (= spinosauroid, e.g., Benson et al., 2010), so it may group with spinosaurids in this cladogram.

Fig. 1.- Filogenia (“árbol genealógico”) de los dinosáurios terópodos, con imágenes de cráneos de los grupos más importantes de grandes carnívoros de Asia. Terópodos basales como Monolophosaurus, pertenecientes a clados endémicos, ocuparon el nicho de gran carnívoro durante el Jurásico medio. Sinraptóridos allosauroideos y carcharodontosáuridos fueron los carnívoros ubicados en la cima de la cadena alimenticia durante el Jurásico tardío y el Cretácico temprano-medio de Saia, respectivamente. Durante los últimos 20 millones de años del Cretácico, clados derivados de terópodos coelurosaurios alcanzaron grandes tallas, notablemente tiranosáuridos como Tarbosaurus.

here, but only medium-to-large-bodied taxa that were likely apex predators, or otherwise occupied a top predator niche.

\section{Overview of Asian Large-Bodied Theropods}

Large-bodied theropods first appear in the Asian fossil record during the Middle Jurassic (Fig. 2). They may have been present during earlier time intervals, but are missing because Late Triassic-Early Jurassic terrestrial sedimentary rocks are rare and often lacking in fossils. Indeed, theropod specimens from the Late Triassic and Early Jurassic are exceptionally uncommon (Weishampel et al., 2004; Zhao et al., 2008). However, the absence of large theropods in the well-sampled Early Jurassic Lufeng Formation may be a genuine signal. Large-bodied theropods, of sizes comparable to those of the Middle Jurassic and later in dinosaur history, are essentially 
unknown from the Triassic and Lower Jurassic globally. The earliest truly large taxon is Shidaisaurus (Wu et al., 2009) from the early Middle Jurassic of Asia. This is contemporaneous with, or slightly pre-dates, the emergence of large theropods in the Bathonian of Europe (Megalosaurus: Benson, 2010).

The Lower Lufeng Formation of Yunnan has yielded what is currently the most informative Early Jurassic theropod from Asia, the holotype of Dilophosaurus sinensis, a nearly complete skeleton of a mid-sized theropod (ca. 5-6 meters long) (Hu, 1993). This specimen was

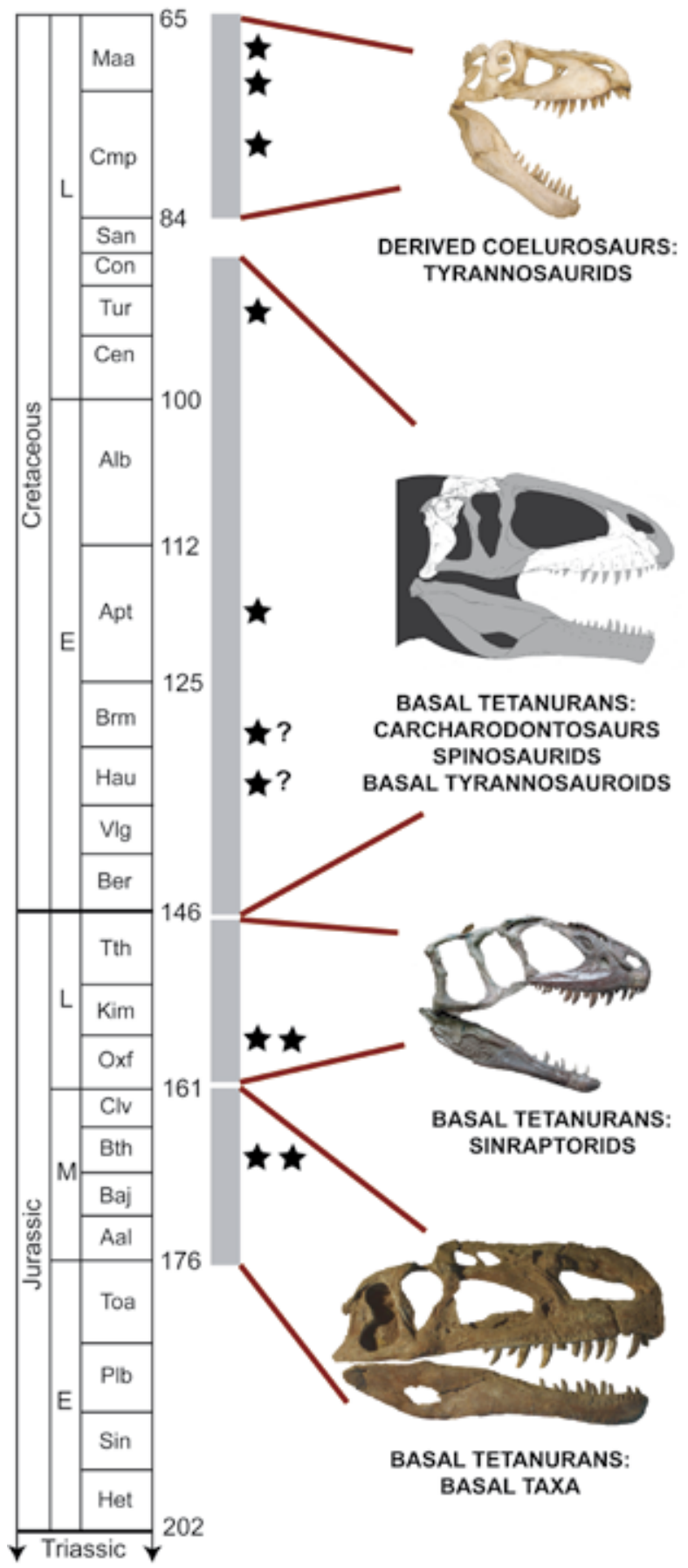

originally referred to the genus Dilophosaurus, as its double-crested skull is extremely similar to that of Dilophosaurus wetherilli from the Early Jurassic of North America (Welles, 1984). Lamanna et al. (1998) disputed this referral and argued that $D$. sinensis was a more derived theropod not particularly closely related to $D$. wetherilli, but Smith et al. (2007) recovered the two taxa as close relatives in a large phylogenetic analysis. Unfortunately, the holotype of $D$. sinensis has only been briefly described. What is clear is that $D$. sinensis is an extremely basal theropod, in concert with its Early Jurassic age, and
Fig. 2.-Schematic diagram illustrating the major groups of large theropod dinosaurs in Asia throughout the Mesozoic. Different theropod groups filled the large predator niche over time, and in general progressively more derived theropods achieved large body size in Asia throughout the Jurassic and Cretaceous. Thick gray bars represent the general durations of the indicated large theropod faunas, whereas stars represent the age of actual fossil sites that preserve large theropods. Question marks indicate uncertain dating of some fossil sites. The timescale on the left is taken from Walker and Geissman (2009).

Fig. 2.-Diagrama esquemático ilustrando los grupos principales de dinosaurios terópodos de Asia durante el Mesozoico. Diferentes grupos de terópodos ocuparon el nicho de gran depredador durante ese tiempo $\mathrm{y}$, en general, formas progresivamente más derivadas alcanzaron grandes tallas corporales en Asia durante el Jurásico y el Cretácico. Las barras en gris representan, en general, la duración de las faunas de terópodos indicadas, mientras que las estrellas representan la edad de las localidades que han proporcionado grandes terópodos. Los interrogantes indican la datación ambigua de algunas localidades fósiles. La escala temporal de la izquierda se obtuvo de Walker and Geissman (2009). 

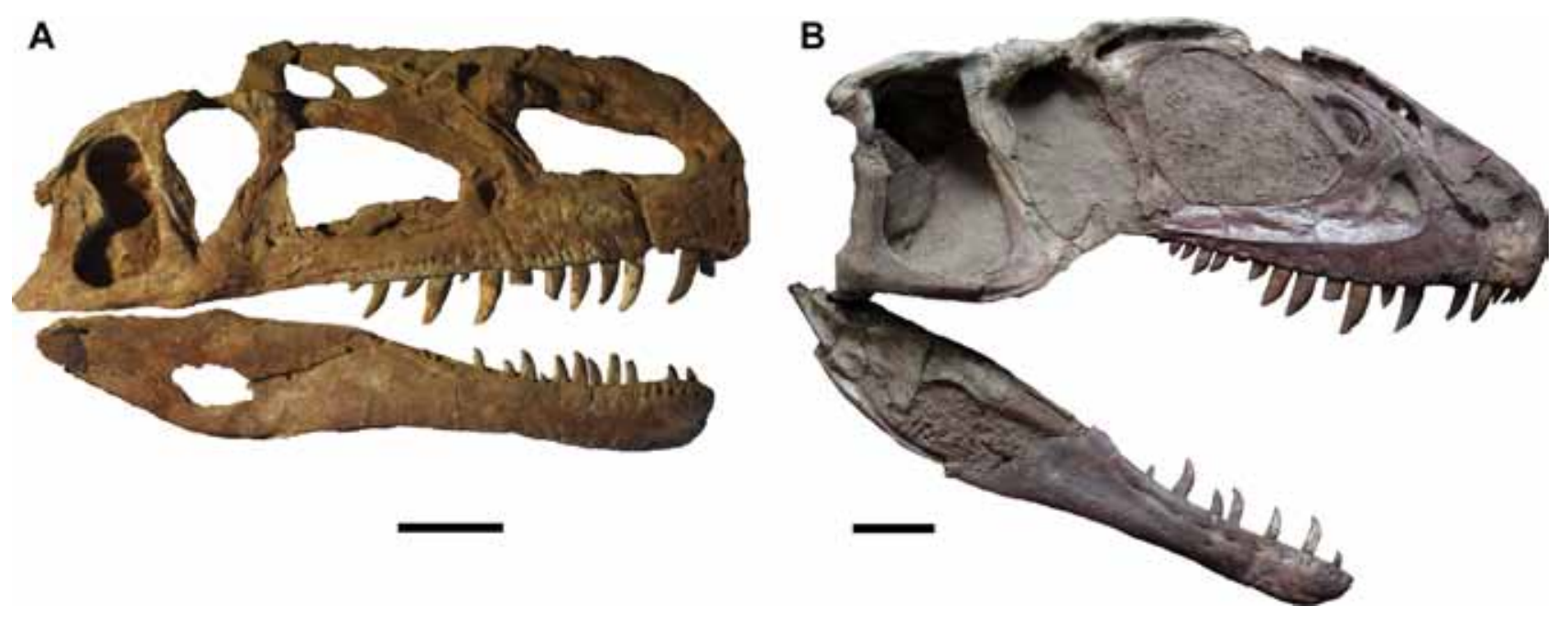

Fig. 3- Skulls of Middle-Late Jurassic Asian theropods in right lateral view. A, Monolophosaurus jiangi (IVPP 84019), Middle Jurassic Shishugou Formation of Xinjiang, China; B, Sinraptor dongi (IVPP 10600), Late Jurassic (Oxfordian) Shishougou Formation of Xinjiang, China. Scale bars equal 10 centimeters.

Fig. 3.- Cráneos de terópodos asiáticos del Jurásico medio-tardío en vista lateral derecha. A, Monolophosaurus jiangi (IVPP 84019), Jurásico medio de la Formación Shishugou de Xinjiang, China; B, Sinraptor dongi (IVPP 10600), Jurásico tardío (Oxfordiense) de la Formación Shishougou de Xinjiang, China. La escala equivale a $10 \mathrm{~cm}$.

is a medium-sized carnivore that is substantially smaller than most of the large-bodied theropods considered in this review.

Subsequently, during the Middle Jurassic, Asia was home to a diverse fauna of medium-to-large-bodied theropods (Figs. 2, 3). Taxa such as Monolophosaurus, Gasosaurus, and 'Szechuanosaurus' are known from well-preserved and substantially complete specimens, and additional taxa are known from more fragmentary remains. China, therefore, boasts the highest taxic diversity of Middle Jurassic theropods of all body sizes from anywhere in the world. Unfortunately, most of these taxa have not been described in detail and their affinities remain uncertain. However, new information suggests that some of these taxa constituted endemic clades, or primitive grades, of basal tetanuran theropods (Zhao et al., 2010), likely a result of the paleogeographic separation of Asia from the rest of Pangea during the Middle Jurassic (Smith et al., 1994; Upchurch et al., 2002).

Later, during the Late Jurassic, Asia was home to the sinraptorid allosauroids (Figs. 2, 3). Often thought to be an endemic clade, sinraptorids are now known from Europe (Mateus, 1998; Benson, 2010), suggesting that large theropod faunas were more cosmopolitan during this time. Such cosmopolitanism was even more apparent during the Early-mid Cretaceous, as carcharodontosaurian and spinosaurid theropods, both widespread clades, filled the large predator niche in Asia at this time (Figs. 2, 4-6). Finally, during the terminal 20 million years of the Cretaceous, the apex predator role was occupied by the colossal tyrannosaurids, a clade otherwise only known from North America (Figs. 2, 7-8). Other derived, birdlike coelurosaurian groups such as the oviraptorosaurs and ornithomimosaurs also developed large body size during this time, although these animals were herbivorous or omnivorous.

In sum, over time different groups of theropods filled the large predator role in Asia, and their distributions reflect the changing paleogeography of the Mesozoic (Fig. 2). During the earliest stage of large-bodied theropod evolution in Asia, the Middle Jurassic, the apex predators belonged to basal theropod clades. Over the next 100 million years, more derived groups of theropods (i.e., those progressively more closely related to birds) developed large body size. The Middle Jurassic large theropod faunas were possibly endemic, whereas Late Jurassic-mid Cretaceous taxa were members of cosmopolitan radiations. By the close of the Cretaceous, however, Asia sported a large theropod fauna of tyrannosaurids and other large coelurosaurs that was similar to faunas in North America, but drastically different from those on the southern continents (Africa, South America, India, Madagascar, Australia). This evolutionary sequence, now understood in unprecedented detail because of the ongoing discovery and description of Asian fossils, is currently the best long-term record of large dinosaur predators on a single landmass.

\section{Middle Jurassic}

Chinese Middle Jurassic theropods were first reported in 1984. Since then, their fossil record has grown stead- 
ily and more Middle Jurassic taxa are known from China than any other geographic region. The occurrence of derived paravian theropods in the Late Jurassic, such as the troodontid Anchiornis from the Oxfordian of China (Xu et al., 2009; Hu et al., 2009) and the avian Archaeopteryx from the Tithonian of Europe (Meyer, 1861), indicate that critical phases in theropod diversification, body size evolution, and the acquisition of avian biological traits took place in the Middle Jurassic. As a source of continuing discoveries, China has great potential to shed light on this important episode in theropod history, especially concerning large-bodied theropod evolution.

The Xiashaximiao Formation (late Middle Jurassic) of Sichuan Province has yielded Xuanhanosaurus (Dong, 1984), 'Szechuanosaurus' zigongensis (Gao, 1993), Kaijiangosaurus lini (He, 1984), Chuandongocoelurus primitivus (He, 1984) and Gasosaurus constructus (Dong \& Tang, 1985). Shidaisaurus jinae was recently reported from the base of the Upper Lufeng Formation (early Middle Jurassic) (Wu et al., 2009) and Monolophosaurus is known from the ?mid-Bathonian-late Callovian (D. Eberth, pers. comm. 2009) part of the Shishougou Formation of Xinjiang Uyghur Autonomous Region (Zhao and Currie, 1994) (Fig. 3A). Most of these taxa pertain to mid-to-large-bodied theropods, and most are known from associated postcranial skeletons.

Most Middle Jurassic theropods from China are generally 'medium-sized' (Table 1; Gasosaurus), as are the majority of Middle Jurassic theropods globally. However, Chuandongocoelurus is exceptionally small among basal tetanurans (Table 1), with an estimated mass of only 13 $\mathrm{kg}$. The large-bodied Shidaisaurus is from the other end of the body size spectrum, as its ilium is $620 \mathrm{~mm}$ long (Wu et al., 2009). This is shorter than the largest ilia of Megalosaurus (>832 mm; Benson, 2010) from the Bathonian (Middle Jurassic) of the United Kingdom. However, the ilia of Shidaisaurus are taller dorsoventrally relative to their length, perhaps indicating that Shidaisaurus was only slightly smaller than Megalosaurus (estimated body mass approximately $1000 \mathrm{~kg}$; Anderson et al., 1985; Benson, 2009a; Benson, 2010). Shidaisaurus, from the lower Middle Jurassic, is the stratigraphically earliest discovery of truly large body size in theropods and may represent the emergence of giant predators for the first time in dinosaur history. Alternatively, their absence in older deposits may simply await further exploration.

The taxonomy and systematics of Middle Jurassic theropods have long been neglected. This is largely due to a paucity of data, as the Middle Jurassic dinosaur record is poorly sampled globally (e.g. Weishampel et al. 2004). However, recent reviews and revisions have focused on the Chinese taxon Monolophosaurus (Brusatte et al., 2010a; Zhao et al., 2010) and the European Middle Jurassic theropod record (Allain, 2001, 2002, 2005; Allain and Chure, 2002; Benson, 2009a, b; and 2010; Benson et al., 2008; Sadleir et al., 2008). As a result, the relationships of many Middle Jurassic taxa are now better understood (Smith et al., 2007; Benson, 2010). The emerging pattern suggests that during the Middle Jurassic, theropods from the three well-sampled regions (Argentina, China, and Europe) formed geographically localized, perhaps 'endemic' clades (Smith et al., 2007; Zhao et al., 2010; Benson, 2010).

Unfortunately, most Chinese Middle Jurassic theropods have not been described in detail since their original publication. As such, their affinities remain uncertain. However, Monolophosaurus and Chuandongocoelurus show an intriguing combination of derived, tetanuran synapomorphies and primitive features shared with non-tetanurans, which together suggest a basal position within Tetanurae (Zhao et al., 2010). Therefore, understanding the anatomy of Chinese Jurassic taxa may reveal further details of primitive tetanuran anatomy and thus help to resolve the early evolution of this taxonomically diverse and successful theropod clade. Furthermore, the possibility of Middle Jurassic dinosaur provincialism can only be tested by detailed restudy of Chinese Middle Jurassic theropods, coupled with better resolution of the specieslevel phylogeny of other dinosaur groups. In summary, future exploration of the Chinese Middle Jurassic theropod record promises to yield new insights into the diversification of Tetanurae, the origin of large body size among theropods, and Middle Jurassic paleobiogeography.

\section{Late Jurassic}

Large-bodied Late Jurassic theropods are well-known globally, especially compared to earlier time intervals, and the Chinese record is no exception. Most taxa were referred to the basal allosauroid clade Sinraptoridae by Currie and Zhao (1994), who provided an excellent description of Sinraptor dongi (Fig. 3B). Other taxa have only been preliminarily described, which obstructs our understanding of their systematic placement.

The first reported Late Jurassic Asian theropod taxon, Szechuanosaurus campi, was discovered in China over a half century ago (Young, 1942). The holotype of $S$. campi is a series of four teeth from the early Late Jurassic (Oxfordian-early Kimmeridgian: Peng et al., 2005) Shangshaximiao Formation. Unfortunately, these fossils have been considered undiagnostic (Chure, 2000), thus rendering $S$. campi a nomen dubium. A partial skeleton referred to Szechuanosaurus campi (Dong et al., 1983) has also been described from the Shangshaximiao For- 


\begin{tabular}{|c|c|c|c|c|c|c|c|}
\hline & & $\begin{array}{l}\text { Maxilla length or } \\
\text { other measurement }\end{array}$ & $\begin{array}{l}\text { Femur } \\
\text { length }\end{array}$ & $\begin{array}{l}\text { Femur } \\
\text { circumference }\end{array}$ & $\begin{array}{l}\text { Mass } \\
\text { estimate } \\
(\mathbf{k g})^{1}\end{array}$ & $\begin{array}{l}\text { Mass } \\
\text { estimate } \\
(\mathbf{k g})^{2}\end{array}$ & Source \\
\hline \multirow{3}{*}{$\begin{array}{l}\text { Lower } \\
\text { Jurassic }\end{array}$} & $\begin{array}{l}\text { 'Dilophosaurus' } \\
\text { sinensis }\end{array}$ & 350 & 590 & 220 & 397 & 436 & LDM Z10 \\
\hline & Cryolophosaurus $\S$ & - & 780 & 238 & 492 & 1072 & FMNH PR 1821 \\
\hline & $\begin{array}{l}\text { Dilophosaurus } \\
\text { wetherilliई }\end{array}$ & 350 (UCMP 77270) & 557 & 160 & 166 & 362 & UCMP 37302 \\
\hline \multirow{2}{*}{$\begin{array}{l}\text { Middle } \\
\text { Jurassic }\end{array}$} & Chuandongocoelurus & - & 205 & 63 & 13 & 14 & GCC 20010 \\
\hline & Gasosaurus & - & 470 & - & - & 210 & Dong and Tang 1985 \\
\hline \multirow{3}{*}{$\begin{array}{l}\text { Late } \\
\text { Jurassic }\end{array}$} & Sinraptor dongi* & 420 & 876 & & - & 1559 & Currie and Zhao 1994 \\
\hline & Sinraptor hepingensis & 495 & 980 & - & - & 2237 & Gao 1999 \\
\hline & $\begin{array}{l}\text { Yangchuanosaurus } \\
\text { shangyuensis }\end{array}$ & 500 & 850 & - & - & 1414 & Dong et al. 1983 \\
\hline \multirow{3}{*}{$\begin{array}{l}\text { Early } \\
\text { Cretaceous }\end{array}$} & Fukuiraptor & - & 507 & 164 & 178 & 268 & Currie and Azuma 2006 \\
\hline & Kelmayisaurus & Dentary length $=523$ & - & - & - & & IVPP V 4022 \\
\hline & Sinotyrannus & Ilium length $=770$ & & & & & Ji et al. 2009 \\
\hline \multirow{9}{*}{$\begin{array}{l}\text { Late } \\
\text { Cretaceous }\end{array}$} & Chilantaisaurus & - & 1190 & 432 & 2506 & 4182 & Benson and $\mathrm{Xu} 2008$ \\
\hline & Shaochilong & $\begin{array}{l}\text { Maxillary tooth row } \\
\text { length }=255\end{array}$ & - & - & - & & Brusatte et al. 2009a \\
\hline & Alioramus* & 430 & 560 & 170 & 196 & 369 & Brusatte et al. 2009b \\
\hline & Beishanlong & - & 660 & - & - & 626 & Makovicky et al. 2010 \\
\hline & Deinocheirus & Humerus length $=938$ & - & - & - & & Osmólska and Roniewicz, 1970 \\
\hline & Gallimimus & - & 673 & 216 & 378 & 667 & Christiansen and Farina 2004 \\
\hline & Gigantoraptor & - & 1100 & 352 & 1433 & 3246 & Xu et al. 2007 \\
\hline & Suzhousaurus & - & 840 & - & - & 1362 & Li et al. 2008 \\
\hline & Tarbosaurus & $630($ ZPALMgD-I/4) & 854 & 312 & 1031 & 1436 & Christiansen and Farina 2004 \\
\hline
\end{tabular}

Table 1. Measurements of the femur and other skeletal elements indicating body size in theropods. Most listed taxa are Asian theropods, but a sample of non-Asian taxa, which are close relatives of less complete Asian taxa, are included for comparative purposes (these are denoted by by $\S$ after the taxon name). Two mass estimates are presented: based on femur circumference, as calculated by equations in Alexander et al. (1985) and denoted by 1 ; based on femur length, as calculated by Christiansen and Fariña (2004) and denoted by 2 . The symbol * denotes measurements from immature specimens. All measurements are in millimeters unless otherwise indicated. Abbreviations: FMNH, Field Museum of Natural History, Chicago, USA; GCC, Geological College of Chengdu, China; IVPP, Institute of Vertebrate Paleontology and Paleoanthropology, Beijing, China; LDM, Lufeng Dinosaurs Museum, Yunnan, China; UCMP, University of California Museum of Paleontology, Berkeley, USA; ZPAL, Institute of Palaeobiology, Warsaw, Poland.

Tabla 1. Medidas del fémur y otros elementos esqueléticos indicando tamaño corporal en terópodos. Las estimaciones de masa corporal se basan en la circunferencia femoral, calculadas a partir de las ecuaciones de Alexander et al. (1985). Aquellos taxones de fuera de Asia están indicados con $\S$ después del nombre del taxón, mientras que * denota medidas realizadas en especímenes inmaduros. Abreviaturas: FMNH, Field Museum of Natural History, Chicago, USA; GCC, Geological College of Chengdu, China; IVPP, Institute of Vertebrate Paleontology and Paleoanthropology, Beijing, China; LDM, Lufeng Dinosaurs Museum, Yunnan, China; UCMP, University of California Museum of Paleontology, Berkeley, USA; ZPAL, Institute of Palaeobiology, Warsaw, Poland.

mation of Sichuan. This specimen was only briefly described by Dong et al. (1983) and its affinities are poorly resolved. It has not been included in many phylogenetic analyses, but Holtz et al. (2004) found it as the most basal tetanuran. The ischium of this specimen is $420 \mathrm{~mm}$ long, comparable to 'medium' sized theropods such as Piatnitkzysaurus (ischium length $=423 \mathrm{~mm}$; mass estimated at $504 \mathrm{~kg}$ based on a femoral circumference of $240 \mathrm{~mm}$; Anderson et al., 1985) and most Chinese Middle Jurassic theropods.

Other large-bodied Chinese theropods are larger than this supposed Szechuanosaurus specimen, with femoral lengths comparable to some individuals of the tyrannosaurid Tarbosaurus (Table 1). These taxa are all sinrap- torids (Currie and Zhao, 1994): Sinraptor hepingensis (Gao, 1992, 1999), Yangchuanosaurus shangyouensis (Dong et al., 1978), and Yangchuanosaurus magnus (Dong et al., 1983) from the Shangshaximiao Formation of Sichuan, and Sinraptor dongi (Currie and Zhao, 1994) from the Shishougou Formation (Oxfordian) of Xinjiang (Fig. 3B). Sinraptorids were also present elsewhere in Asia, as recently a tibia pertaining to this group was described from the Phu Kradung Formation of Thailand, a unit with poor age constraint that may be Late Jurassic or possibly Early Cretaceous in age (Buffetaut and Suteethorn, 2007). Some of these taxa may have grown to enormous sizes: a possible sinraptorid lateral tooth from the Shishugou Formation represents the larg- 

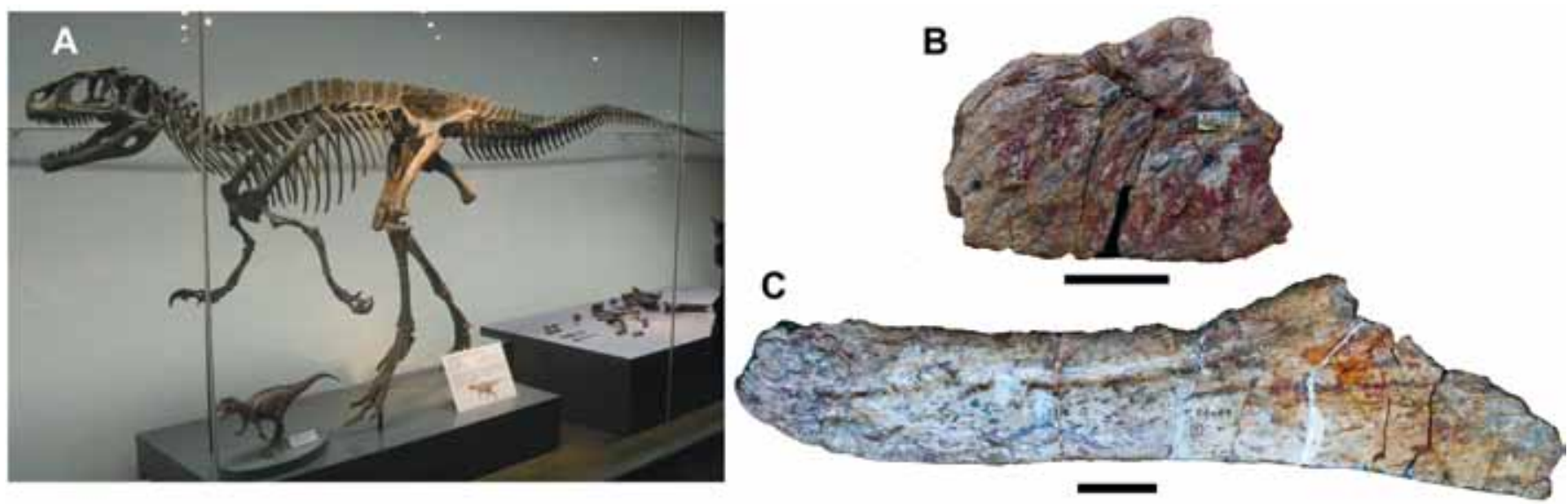

Fig. 4- Early Cretaceous Asian theropods. A, Fukuiraptor kitadaniensis, Late Hauterivian-Barremian of Japan; B and C, Kelmayisaurus petrolicus, (?Valanginian-Albian of Xinjiang, China. B, left maxilla fragment in lateral view; C, left dentary in lateral view. Scale bars equal 5 centimeters. Photograph in A courtesy of Dave Hone.

Fig. 4.- Terópodos del Cretácico temprano de Asia. A, Fukuiraptor kitadaniensis, Hauteriviense tardío-Barremiense de Japón; B y C, Kelmayisaurus petrolicus, (?Valanginiense-Albiense de Xinjiang, China. B, fragmento de maxilar izquierdo en vista lateral; C, dentario izquierdo en vista lateral. La escala equivale a $5 \mathrm{~cm}$. Fotografía en A cortesía de Dave Hone.

est reported theropod tooth from the Jurassic and is comparable in size to the lateral teeth of Tyrannosaurus (Xu and Clark, 2008). However, other sinraptorids, such as the recently described Leshansaurus from the Shangshaximiao Formation, may have been somewhat smaller (femur length of approximately 60 centimeters: Li et al., 2009). Until recently, sinraptorids were often regarded as a uniquely Asian radiation (e.g., Allain, 2002). However, restudy of Metriacanthosaurus from the Oxfordian of the United Kingdom suggests that it is nested within the clade, as may be the Late Jurassic Portuguese theropod Lourinhanosaurus and the Middle Jurassic French taxon Poekilopleuron (Benson, 2010; Benson et al., 2010). If these placements are corroborated they may indicate that Asia was home to cosmopolitan (or at least Europeaninfluenced) large theropods during the Late Jurassic, in contrast to the more endemic nature of Middle Jurassic faunas.

\section{Early - early Late Cretaceous}

Large-bodied theropod fossils from the Early-mid Cretaceous (ca. 145.5-83.5 million years ago) are rare in Asia (Weishampel et al., 2004; Zhao et al., 2008). Only a small sample of specimens is known, most of which were discovered and described several decades ago (e.g., $\mathrm{Hu}$, 1964; Dong, 1973). Most of these were described and figured only briefly, and as a result, their taxonomy and phylogenetic relationships have been contentious (Chure, 2001; Rauhut, 2003a). However, in recent years, important specimens from the Early-mid Cretaceous of China have been restudied, redescribed, and reassessed (Ben- son and Xu 2008; Brusatte et al., 2009a; Benson et al., 2010; Brusatte et al. 2010b), and critical new specimens from Japan (Azuma and Currie, 2000; Currie and Azuma, 2006) and Thailand (Buffetaut et al., 1996, 2008; Milner et al., 2007) have come to light. Together, this new information has helped to illuminate what was previously a 60-million-year dark period in the fossil record of large Asian theropods.

\subsection{Early Cretaceous of China, Japan, and Thailand}

Early Cretaceous large-bodied theropod fossils are rare in Asia, but substantially complete and informative specimens are known from three countries: China, Japan, and Thailand.

In China, only a single decent specimen of a large Early Cretaceous theropod is known. Described by Dong (1973), this partial skull is comprised of a fragmentary left maxilla and a nearly complete left dentary, and is from the poorly constrained Lianmugin Formation (?Valanginian-Albian) of Xinjiang (Fig. 4B,C). It was named by Dong (1973) as a new genus and species, Kelmayisaurus petrolicus, but has been dismissed by many subsequent authors as a nomen dubium because of its fragmentary nature (e.g., Rauhut and Xu, 2005). Similarly, its phylogenetic relationships are poorly resolved, and most authors have regarded it as a basal tetanuran theropod of uncertain affinities (e.g., Molnar et al., 1990; Holtz et al., 2004). Recent reexamination of the material, however, reveals that Kelmayisaurus can be diagnosed by a single autapomorphy (a deeply inset and dorsally concave "accessory" groove located anteriorly on the lateral surface 
of the dentary) and shares features with the carcharodontosaurian theropods, a cosmopolitan subclade of allosauroids that includes some of the largest terrestrial predators to ever live. Some of these features, however, are also seen in large megalosauroids such as Megalosaurus and Torvosaurus. The precise affinities of Kelmayisaurus remain unclear, but this taxon is the subject of ongoing study (Brusatte, Benson, and $\mathrm{Xu}$, in prep).

In Japan, the Kitadani Formation (Late HauterivianBarremian: Kobayashi and Azuma, 2003) of Fukui Prefecture has yielded numerous associated and isolated remains of another carcharodontosaurian, Fukuiraptor kitadaniensis (Azuma and Currie, 2000; Currie and Azuma, 2006) (Fig. 4A). Fukuiraptor is one of the smallest allosauroid theropods known, with an estimated body mass of 175 kilograms, but is included here since its closest relatives are large-bodied taxa. Fukuiraptor was originally described as a basal tetanuran theropod, likely an allosauroid, but its more precise phylogenetic affinities have proven elusive (Brusatte and Sereno, 2008; Hocknull et al., 2009; Benson, 2010). The recent discovery of the Australian allosauroid Australovenator (Hocknull et al., 2009) and the South American taxon Aerosteon (Sereno et al., 2008), along with the monographic description of the European carcharodontosaurian Neovenator (Brusatte et al., 2008), has allowed for a revision of allosauroid phylogeny (Benson et al., 2010). In this recent analysis, Fukuiraptor is found to be the sister taxon of Australovenator, and both taxa are members of a speciose clade of basal carcharodontosaurians, Neovenatoridae. This clade is cosmopolitan, and in addition to the Asian and Australian forms also includes taxa from Europe (Neovenator) and South America (Aerosteon, Megaraptor, Orkoraptor). Additionally, some neovenatorids survived until late into the Cretaceous, and some taxa (such as Fukuiraptor) are sleek, mid-sized animals that convergently share many features of the appendicular skeleton and the extent of postcranial pneumaticity with bird-like coelurosaurian theropods. In essence, Fukuiraptor and other neovenatorids are more basal theropods mimicking more derived theropods (which are more closely related to birds).

In Thailand, three Early Cretaceous units have yielded remains of two cosmopolitan theropod clades, Allosauroidea and Spinosauridae. The holotype and only known specimen of Siamotyrannus isanensis, which comprises much of the pelvis, sacrum, and tail of a ca. 6.5-meter-long theropod, is known from the Aptian or older Sao Khua Formation (Racey et al., 1996; Buffetaut and Suteethorn, 1999). Siamotyrannus was originally described as a primitive member of the tyrannosauroid lineage, and one of the oldest members of the group
(Buffetaut et al., 1996). However, more recently it has been reinterpreted as a more basal theropod, likely an allosauroid (Rauhut, 2003a; Holtz et al., 2004; Brusatte and Sereno, 2008). Its more precise affinities, however, remain questionable. Spinosaurid theropods are known from several teeth from the Sao Khua Formation (Buffetaut and Ingavat, 1986), as well as other Early Cretaceous units in southern China (Buffetaut et al., 2008) and Japan (Hasegawa et al., 2003), and the mid Cretaceous Majiacun Formation of Henan Province, China (Hone et al., 2010). Most striking, however, is an as-yet-undescribed partial postcranial skeleton of a spinosaurid from the Aptian Khok Kruat Formation of Thailand (Milner et al., 2007). The discovery of Asian spinosaurids is notable, as previously this group was only known from the Early Cretaceous of Africa, Europe, and South America. It is likely that spinosaurids, like carcharodontosaurians, were a widespread clade during the Early Cretaceous.

Finally, one newly described, fragmentary specimen from the Jehol Biota (Jiufotang Formation, Early Cretaceous) of Liaoning, China deserves comment. Ji et al. (2009) described a fragmentary skull and postcranial remains as a new species of large tyrannosauroid, $\mathrm{Si}$ notyrannus kazuoensis, which they estimated may have reached a body length of 9-10 meters. The preserved remains are indeed large, and the ilium (770 mm long anteroposteriorly) is substantially larger than that of other Late Jurassic-Early Cretaceous tyrannosauroids, including "mid-sized" forms such as Stokesosaurus (ilium length $=523 \mathrm{~mm}$; see below). Ji et al. (2009) suggested that Sinotyrannus may represent an early and primitive member of Tyrannosauridae, the derived subclade of colossal tyrannosauroids otherwise restricted to the Campanian and Maastrichtian (see below). This assessment was based on its large body size, along with one feature of the maxilla (maxillary fenestra overlapped laterally by the lateral lamina) that is seen in only some tyrannosaurids (Daspletosaurus, Tarbosaurus, Tyrannosaurus: Holtz 2001).

However, it is clear that Sinotyrannus is a more basal tyrannosauroid. First, the basal Early Cretaceous tyrannosauroid Eotyrannus also possesses a maxillary fenestra obscured by the lateral lamina (IWCMS 1997.550), rendering this character homoplastic. Second, Sinotyrannus possesses several unique features shared with basal tyrannosauroids such as Guanlong and Proceratosaurus, including an enlarged external naris, midline nasal crest, an anterior ramus of the maxilla, and a sharp and deep neurovascular groove on the dentary (Xu et al., 2006; Rauhut et al., 2010). It is possible that Sinotyrannus forms a clade with these taxa, a hypothesis that remains to be tested by 
phylogenetic analysis. In any event, Sinotyrannus is likely to be a basal tyrannosauroid that developed large body size independently of derived tyrannosaurids.

\subsection{Mid Cretaceous of China}

Two substantial, informative specimens of large theropods are known from the Turonian (ca. 92 million years old) Ulansuhai Formation of Inner Mongolia (Figs. 5, 6). Both specimens were originally described by $\mathrm{Hu}$ (1964), who referred them to multiple species of the genus $\mathrm{Chi}$ lantaisaurus, C. tashuikouensis (the type species of the genus) and C. maortuensis. The C. tashuikouensis holotype comprises a partial postcranial skeleton of a colossal individual (Fig. 5), which may have reached a body size similar to the giant carcharodontosaurians Acrocanthosaurus and Mapusaurus, and perhaps even Tyrannosaurus (Benson and $\mathrm{Xu}, 2008)$. The C. maortuensis holotype, on the other hand, includes several cranial bones and vertebrae from a much smaller individual (Fig. 6). Due to the lack of overlapping elements, as well as the considerable size difference, between the two specimens, authors have long argued that $C$. maortuensis cannot reliably be placed in the same genus as C. tashuikouensis (Chure, 1998, 2001; Rauhut, 2003a; Benson and Xu, 2008). This suggestion was followed by Brusatte et al. (2009a), who recently erected a new genus for C. maortuensis, Shaochilong.

Both Chilantaisaurus and Shaochilong were largely neglected for several decades after Hu's (1964) original descriptions, resulting in uncertainty over their phylogenetic placement (e.g., Harris, 1998; Rauhut, 2003a). Only recently have the two specimens been redescribed and restudied in a phylogenetic context (Benson and $\mathrm{Xu}, 2008$; Brusatte et al., 2009a; Brusatte et al., 2010b). Both are strongly placed within the carcharodontosaurian theropods, Shaochilong as a close relative of South American and African taxa (Carcharodontosaurus, Giganotosaurus, Mapusaurus, Tyrannotitan) and Chilantaisaurus as a neovenatorid, a member of the same clade as Fukuiraptor from the Early Cretaceous of Japan (Benson et al., 2010). Therefore, both taxa are members of speciose and cosmopolitan carcharodontosaurian subclades. Combined with the possible carcharodontosaurian affinities of $\mathrm{Kel}$ mayisaurus, from the Early Cretaceous of China, these specimens suggest that carcharodontosaurians had a long history on the Asian continent. The presence of two carcharodontosaurians in the Turonian of China also indicates that more basal theropods continued to fill the large predator niche in Asia at this time, not tyrannosaurids or their precursors. Interestingly, the substantial size differ- ence between the contemporary Shaochilong and Chilantaisaurus suggests that carcharodontosaurians may have filled a variety of body size and ecological niches during the middle Cretaceous (Benson et al., 2010).

\subsection{Paleobiogeography, Evolution, and Faunal Change}

Very little was known about the evolution of Earlymid Cretaceous large-bodied theropods in Asia until very recently. The redescriptions of Shaochilong and Chilantaisaurus, coupled with the discovery of spinosaurids in Thailand and phylogenetic revision of Fukuiraptor and other allosauroids, have helped clarify what was previously a 60-million-year dark period in the Asian large theropod record. The most significant result of this new research is that Asia was home to a cosmopolitan large theropod fauna during this time. These theropods, including carcharodontosaurians and spinosaurids, belong to basal tetanuran clades. The more primitive, endemic clades of the Middle Jurassic apparently did not persist into the Early Cretaceous. Similarly, there is only limited evidence that tyrannosaurids and other derived coelurosaurs, the dominant large theropods of the CampanianMaastrichtian of Laurasia, developed large body size and filled the apex predator niche earlier in time. Instead, the large predators during the Early-mid Cretaceous of Asia belonged to the same groups that dominated the apex niche on other continents during this time. This is not surprising, as Asia was physically reconnected to other landmasses during the Early Cretaceous after the severing of long-standing topographic and oceanic barriers, which had previously isolated Asia for much of the Jurassic (Russell, 1993; Upchurch et al., 2002). Most importantly, regression of the Turgai Sea during the ca. Aptian-Albian resulted in the formation of a European-Asian land connection, which would have allowed terrestrial migration (Smith et al., 1994). Asian sauropods (Upchurch, 1995; Barrett et al., 2002), ornithopods (Norman, 1998), and small-bodied theropods (Xu and Norell, 2006) were also members of cosmopolitan clades during the Early-mid Cretaceous.

A paucity of large theropod taxa from the middle Cretaceous of North America and Europe severely hampers a detailed assessment of biogeography of this age. However, the close relationship between Shaochilong and African and South American carcharodontosaurids, as well as the discovery of Asian spinosaurids (a clade that is also known from Europe, Africa and South America), strengthen hypotheses of faunal exchange between the northern and the southern continents as late as the early Late Cretaceous, as suggested by Brusatte et al. (2009a). 


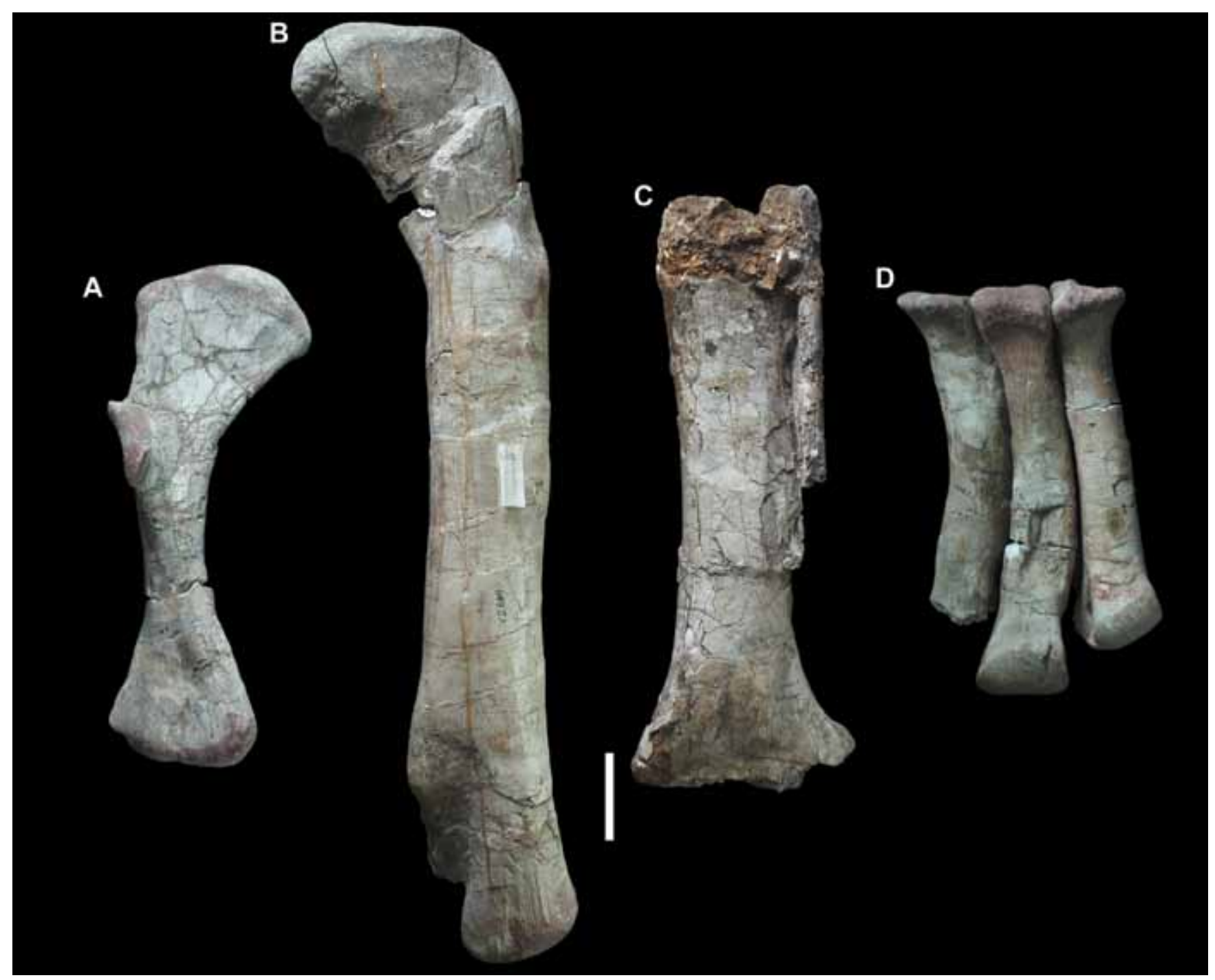

Fig. 5- A montage of select bones from Chilantaisaurus tashuikouensis (IVPP V2884) from the mid Cretaceous (Turonian) of Inner Mongolia, China. A, right humerus in anterior view; B, left femur in anterior view; C, left tibia and fibula in anterior view; D, right metatarsus in anterior view. Scale bar equals 10 centimeters.

Fig. 5.- Selección de huesos de Chilantaisaurus tashuikouensis (IVPP V2884) del Cretácico medio (Turoniense) de Mongolia Interior, China. A, húmero derecho en vista anterior; B, femur izquierdo en vista anterior; C, tibia y fíbula izquierdas en vista anterior; D, metatarso derecho en vista anterior. La escala equivale a $10 \mathrm{~cm}$.

Faunal similarities have already been noted between Asia and North America (Russell, 1993). Therefore, Early-mid Cretaceous Asia was home to some dinosaur taxa with North American affinities, and others with southern influence. Together, these various biotic affinities are consistent with suggestions that dinosaur faunas of this age were effectively cosmopolitan (e.g., Barrett et al., 2002; Benson et al., 2010; Brusatte et al., 2010b).

Several explanations are possible for the observed pattern of Early-mid Cretaceous dinosaur cosmopolitanism. First, although Pangea had begun to fragment tens of millions of years before this time, faunal interchange during the Early-mid Cretaceous may have been possible via various dispersal corridors. The trans-Turgai land bridge is one possible corridor for faunal interchange between northern and southern continents during this time, as Europe was both connected to Asia and located only a short distance from northern Gondwana during the middle Cretaceous (Smith et al., 1994). However, it is also possible that clades such as Spinosauridae, Carcharodontosauridae and Neovenatoridae achieved global distributions prior to the separation of northern and southern landmasses, long before the Early-mid Cretaceous, and persisted in both Laurasia and Gondwana into the early Late Cretaceous. Testing these alternatives will require not only new fossil specimens, but also detailed phylogenetic reassessments and a careful consideration of sampling biases (e.g., Turner et al., 2009). 

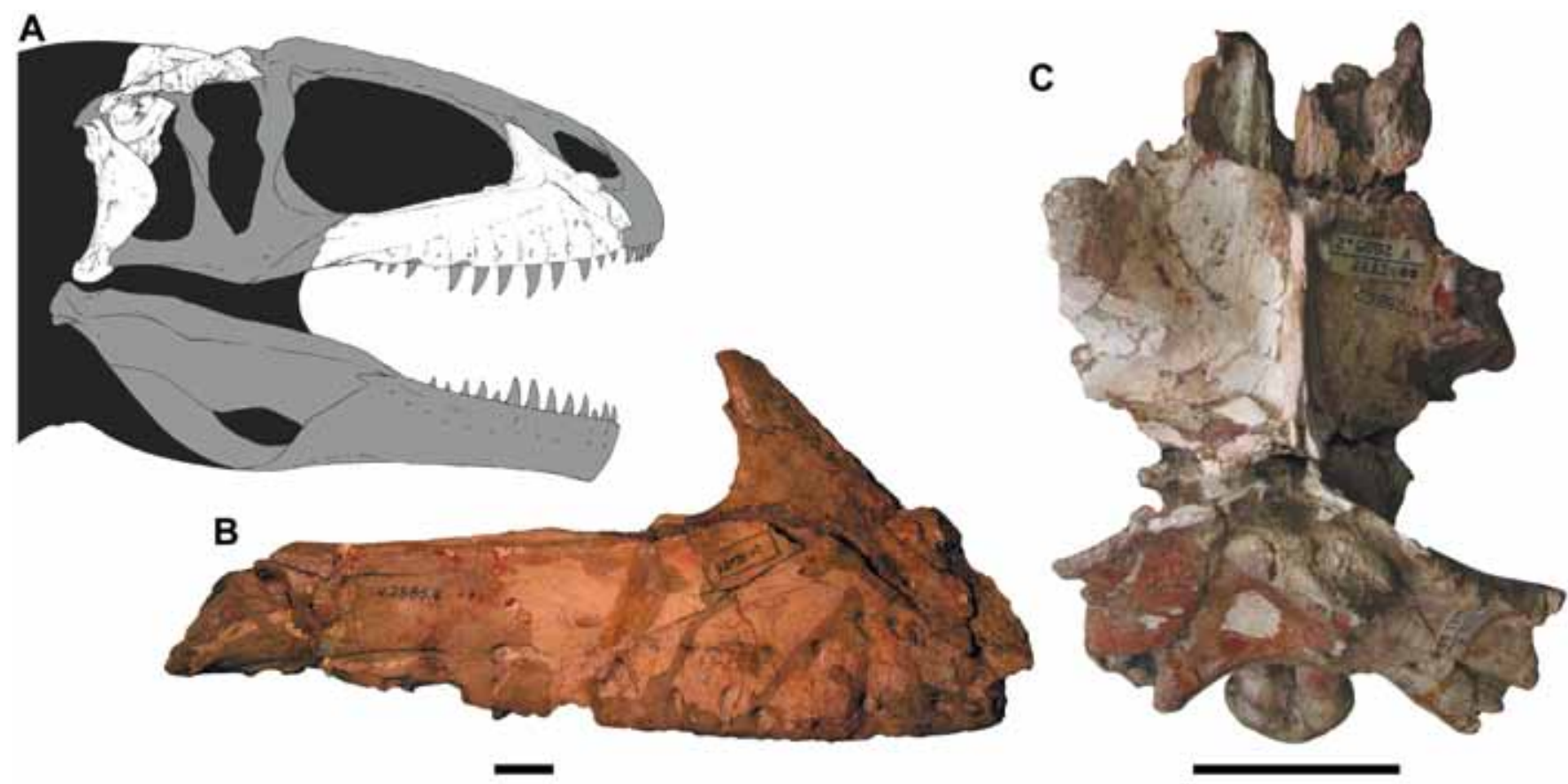

Fig. 6- A skull reconstruction and cranial bones from Shaochilong maortuensis, a small-bodied mid Cretaceous (Turonian) carcharodontosaurian theropod from Inner Mongolia, China. A, skull reconstruction (courtesy of Brett Booth); B, right maxilla in lateral view (IVPP V.2885.4); C, braincase and skull roof in dorsal view (IVPP V.2885.1-2). Scale bars equal 5 centimeters.

Fig. 6.-. Reconstrucción del cráneo y huesos cráneales de Shaochilong maortuensis, carcharodontosáurido de pequeño tamaño del Cretácico medio (Turoniense) de Mongolia Interior, China. A, reconstrucción del cráneo (cortesía de Brett Booth); B, maxilar derecho en vista lateral (IVPP V.2885.4); C, neurocráneo en vista dorsal (IVPP V.2885.1-2). La escala equivale a $5 \mathrm{~cm}$.

The large theropods from the Early Cretaceous of Thailand are interesting to consider in a biogeographic context, as Southeast Asia is comprised of numerous volcanic arcs and accreted terranes, many of which were originally part of Gondwana (Chen et al., 1993; Metcalfe, 2006). Current geophysical evidence indicates that most of Thailand, including the dinosaur-bearing localities, was accreted to the Asian mainland during the Devonian, Permian, and Triassic (Metcalfe, 2006). Therefore, there is no current evidence that Southeast Asia harbored Gondwanan taxa that dispersed northwards upon drifting terranes. However, some of the Tibetan Plateau and surrounding areas are comprised of terranes that may have accreted later, during the Jurassic and Cretaceous (Murphy et al., 1997; Zhang, 1999). Dinosaur fossils are rare in Tibet (Zhao, 1983; Weishampel et al., 2004), but future discoveries may reveal whether the Cretaceous dinosaur faunas of southern Asia had a Gondwanan influence due to terrane accretion.

\section{Terminal Cretaceous (Campanian-Maastrichtian)}

In contrast to the Early-middle Cretaceous, the final 20 million years of the Cretaceous is well represented by a bounty of large-bodied theropod fossils from China and Mongolia (e.g., Currie, 2000; Weishampel et al., 2004). Without exception, all of these large theropods are coelurosaurs, and several are particularly closely related to birds. The most common of these animals, and the undisputed apex predators in the Maastrichtian (and perhaps Campanian) ecosystems of Asia, are the tyrannosaurids (Figs. 7,8). Among the largest terrestrial predators to ever live, tyrannosaurids are some of the most common fossils in the Nemegt Formation and other Maastrichtian units across Asia (Currie, 2000). However, other coelurosaur groups, including the ornithomimosaurs, oviraptorosaurs, and therizinosauroids, also developed large body size during this time, although none of these animals were predators in the traditional sense (Xu et al., 2007). In all, Asia has one of the best records of terminal Cretaceous theropods from anywhere in the world.

\subsection{Campanian-Maastrichtian of China and Mongolia: Tyrannosaurids}

Tyrannosaurids, the subclade of coelurosaurian theropods that includes Tyrannosaurus rex and several close relatives, are only known from the Campanian-Maas- 
trichtian of Asia and North America. In general, tyrannosaurids are characterized by their enormous body size (up to 13 meters long and perhaps five tonnes in mass), large skulls, powerful jaw muscles, horns over the eyes, and atrophied forelimbs (Holtz, 2004). Tyrannosaurids belong to the much more inclusive clade Tyrannosauroidea, an ancient and speciose lineage of theropods that originated by the Middle Jurassic (Rauhut et al., 2010). Some of the oldest and most primitive tyrannosauroids, Guanlong and Dilong, are known from the Late Jurassic and Early Cretaceous of China, respectively (Xu et al., 2004, 2006). However, these taxa, as well as most other basal tyrannosauroids, were mostly small-bodied animals, with few reaching sizes larger than a man (Madsen, 1974; Rauhut, 2003b; Benson, 2008; Rauhut et al., 2010). Some basal tyrannosauroids attained "medium sizes" (i.e., up to four meters long and 300 kilograms in body mass), including Stokesosaurus langhami from the Tithonian (Late Jurassic) of Europe (Benson, 2008) and Xiongguanlong from the Aptian-Albian (Early Cretaceous) of Asia (Li et al., 2010). Regardless, the recent discovery of the basal tyrannosauroid Raptorex from the Barremian-Aptian
(Early Cretaceous) Yixian Formation (He et al., 2006) of Inner Mongolia shows that many of the characteristic tyrannosaurid features, such as the large head, strong jaw muscles, and small forelimbs, originated in a small animal that was only a few meters long and less than 100 kilograms in mass (Sereno et al., 2009).

The major "break" in tyrannosauroid evolution is between the mostly small, primitive Middle Jurassic-Early Cretaceous taxa and the colossal, derived CampanianMaastrichtian tyrannosaurids of North America and Asia. Unfortunately, fossils bridging this break are rare, but Early-mid Cretaceous rocks of Asia hold out great potential for future discoveries. Currently, two unequivocal tyrannosaurids are known from the Maastrichtian of Asia: Tarbosaurus (Fig. 8) and Alioramus (Fig. 7). Furthermore, the puzzling genus Alectrosaurus also inhabited Asia during the Late Cretaceous. Often regarded as a Cenomanian taxon, Alectrosaurus has recently been re-dated as Campanian (Van Itterbeeck et al., 2005). Although Alectrosaurus is clearly a member of the tyrannosauroid lineage, it is unclear whether it is part of the derived tyrannosaurid radiation or whether it represents a

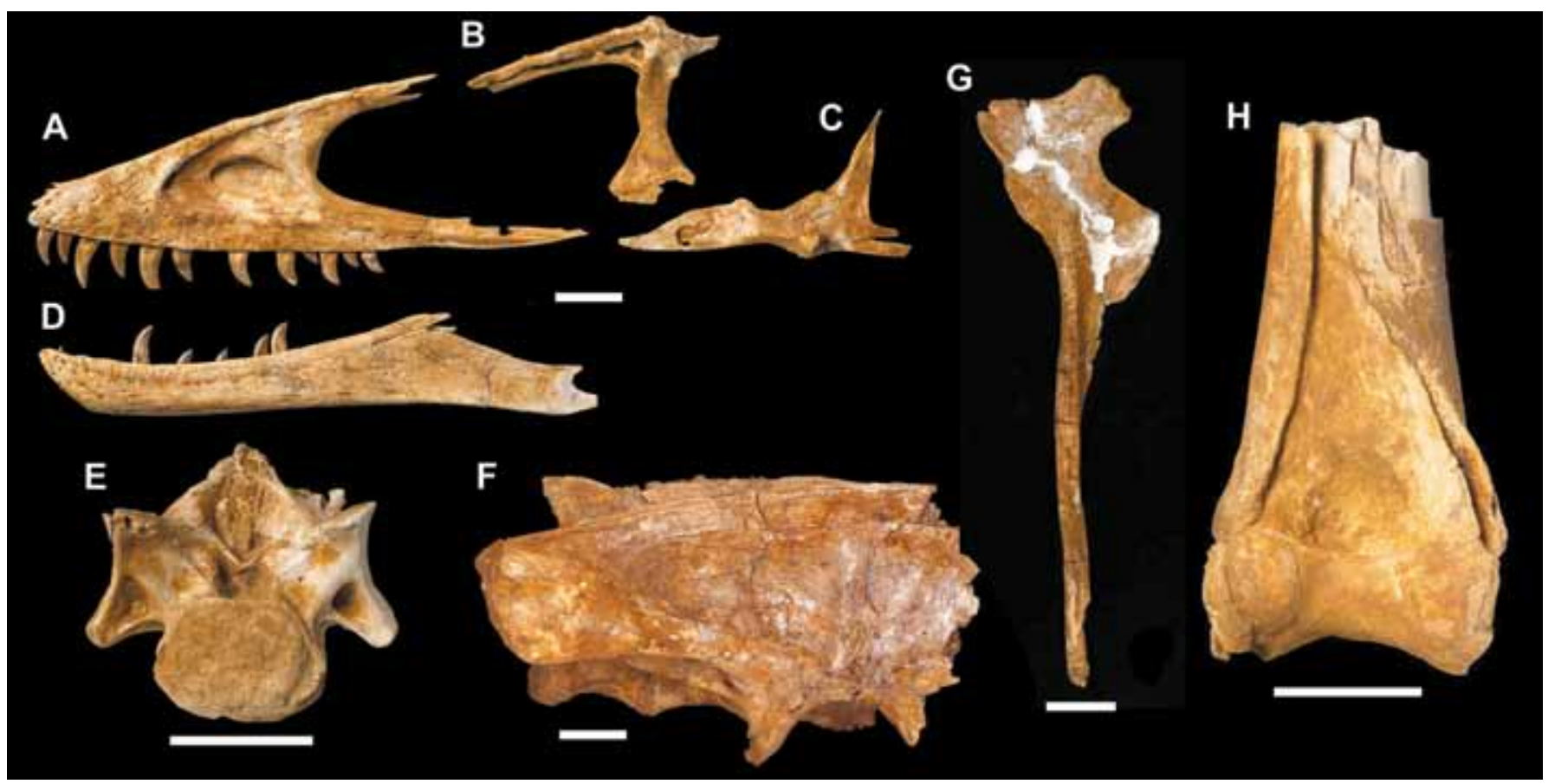

Fig. 7.-A montage of select bones from Alioramus altai (IGM 100/1844), a long-snouted and gracile tyrannosaurid theropod from the Late Cretaceous (Maastrichtian) of Mongolia. A, left maxilla in lateral view; B, left lacrimal in lateral view; C, left jugal in lateral view; D, left dentary in lateral view; E, anterior cervical vertebra in anterior view; F, right ilium in lateral view; G, right ischium in lateral view; H, right crus (tibia, fibula, calcaneum, astragalus) in anterior view. Scale bars equal 5 centimeters. Photographs by Mick Ellison, American Museum of Natural History.

Fig. 7.-Selección de huesos de Alioramus altai (IGM 100/1844), un terópodo tiranosáurido grácil y de rostro alargado correspondiente al Cretácico tardío (Maastrichtiense) de Mongolia. A, maxilar izquierdo en vista lateral; B, lacrimal izquierdo en vista lateral; C, yugal izquierdo en vista lateral; D, dentario izquierdo en vista lateral; E, vértebra cervical anterior en vista anterior; F, íleon derecho en vista lateral; G, isquión derecho en vista lateral; H, parte distal de un miembro inferior (tibia, fíbula, calcáneo, astrágalo) en vista anterior. La escala equivale a $5 \mathrm{~cm}$. Fotografías realizadas por Mick Ellison, American Museum of Natural History. 

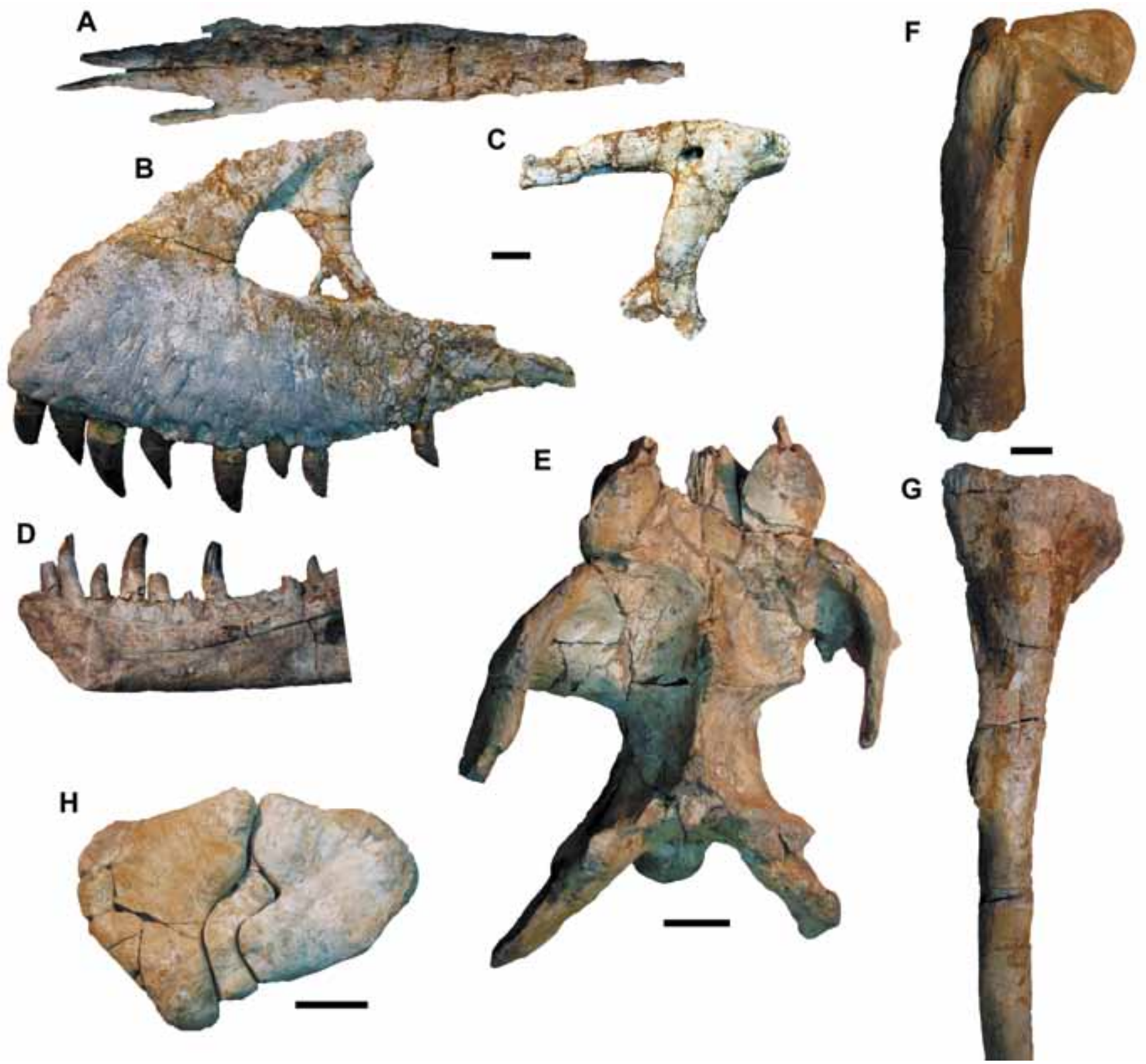

Fig. 8.-A montage of select bones from Tarbosaurus bataar (ZPAL collection), a deep-snouted and robust tyrannosaurid theropod from the Late Cretaceous (Maastrichtian) of Mongolia. A, fused nasal in dorsal view (ZPAL MgD-I/4); B, left maxilla in lateral view (ZPAL MgD-I/4); C, left lacrimal in lateral view (ZPAL MgD-I/4); D, right dentary in medial view (ZPAL MgD-I/5); E, skull roof and braincase in dorsal view (ZPAL MgD-I/3); F, right femur in anterior view (ZPAL MgD-I/109); G, left fibula in lateral view (ZPAL MgD-I/188); H, metatarsals II-IV in proximal view (ZPAL MgD-I/76). Scale bars equal 5 centimeters. One scale bar for A-D and one scale bar for F-G.

Fig. 8.- Selección de huesos de Tarbosaurus bataar (colección ZPAL), un terópodo tiranosáurido robusto y de profundo rostro del Cretácido tardío (Masstrichtiense) de Mongolia. A, nasales fusionados en vista dorsal (ZPAL MgD-I/4); B, maxilar izquierdo en vista lateral (ZPAL MgD-I/4); C, lacrimal izquierdo en vista lateral (ZPAL MgD-I/4); D, dentario derecho en vista medial (ZPAL MgD-I/5); E, basicráneo y parte superior del cráneo en vista dorsal (ZPAL MgD-I/3); F, fémur derecho en vista anterior (ZPAL MgD-I/109); G, fíbula izquierda en vista lateral (ZPAL MgD-I/188); H, metatarsos II-IV en vista proximal (ZPAL MgD-I/76). La escala equivale a $5 \mathrm{~cm}$. Una escala corresponde a A-D y otra a F-G.

more basal tyrannosauroid taxon. The type material, from the Iren Dabasu Formation of Mongolia, has only been briefly described (Gilmore, 1933; Mader and Bradley, 1989), contributing to this uncertainty. It is currently under study by Thomas Carr. Additional material from the Late Cretaceous of Mongolia has been referred to Alec- trosaurus, but these fossils have been poorly described and figured and have been largely inaccessible to many workers (e.g., Perle, 1977).

The unequivocal tyrannosaurid Tarbosaurus is one of the most familiar Asian dinosaurs (Fig. 8). The closest relative (sister taxon) of the iconic Tyrannosaurus rex, 
Tarbosaurus is known from numerous Maastrichtian fossil sites in Mongolia and China (Maleev, 1955, 1974; Currie, 2000; Hurum and Sabath, 2003; Weishampel et al., 2004; Zhao et al., 2008). Tarbosaurus strongly resembles its cousin Tyrannosaurus in most aspects of its anatomy: it was an enormous predator, with a large skull, robust cranial bones, a strongly interlocking lower jaw, rugose brows above the eyes, robust and mediolaterally thickened teeth, and proportionally reduced forelimbs. Like Tyrannosaurus, the skeleton of Tarbosaurus became more stocky and robust, and the skull shorter and deeper, as an individual grew into adulthood (Carr, 1999; Carr and Williamson, 2004). The adult skull of Tarbosaurus was ideally suited for strong bite forces (Erickson et al., 1996; Hurum and Currie, 2000) and an unusual "puncture-pull" feeding style in which the teeth could literally crunch through bone (Erickson and Olson, 1996; Rayfield, 2004).

The second Asian tyrannosaurid, Alioramus, deviates from Tarbosaurus and its other close relatives. Although deeply nested within the tyrannosaurid clade, Alioramus is the only known departure from the "classic" tyrannosaurid body plan (Fig. 7). It does not possess the deep and robust skulls, thick teeth, and stocky skeletons of other tyrannosaurids, but rather has an elongate and weak skull with numerous horn-like projections (Brusatte et al., 2009b). Furthermore, it was approximately half the body size of Tarbosaurus and Tyrannosaurus, with a more gracile, lighter, and pneumatic postcranial skeleton.

Until recently, Alioramus was among the most intriguing, yet poorly-understood large theropod dinosaur genera. It was named by Kurzanov (1976) on the basis of a fragmentary skeleton, including a partial skull that seemed to be long-snouted and gracile. However, because the holotype was incomplete, only briefly described and figured, and largely inaccessible to researchers, many mysteries about Alioramus remained. It was unclear whether Alioramus was a tyrannosaurid proper or a more basal member of the tyrannosauroid stem (Holtz, 2001, 2004; Currie et al., 2003), and some workers even suggested that it may be an aberrant juvenile of Tarbosaurus (Currie, 2003). This debate was put to rest by the recent description of a spectacularly preserved and substantially complete specimen from the Nemegt Formation of Mongolia (Brusatte et al., 2009b).

The new fossil unquestionably shows that Alioramus was smaller and more gracile than its close relatives, and possessed a longirostrine skull. Despite its peculiar body form, Alioramus was recovered as a tyrannosaurid, and indeed a particularly close relative of Tyrannosaurus and Tarbosaurus, in a cladistic analysis (a relationship previ- ously suggested by Currie et al., 2003). Alioramus and Tarbosaurus lived side-by-side during the Maastrichtian, and their divergent body forms may have allowed them to co-exist via ecological niche partitioning. Indeed, the long and weak skull of Alioramus lacks all of the integral components of "puncture-pull" feeding seen in Tarbosaurus, suggesting that Alioramus fed on smaller prey (Brusatte et al., 2009b).

\subsection{Early-Late Cretaceous of China and Mongolia: Oth- er Coelurosaurian Taxa}

Members of other coelurosaurian theropod clades developed large body size during the Early-Late Cretaceous in Asia. However, most of these taxa were not carnivores (Kobayashi et al., 1999; Kobayashi and Lu, 2003; Barrett, 2005; Zanno et al., 2009), and thus did not fill the apex predator role in Asian ecosystems. Examples of giant, non-carnivorous theropods are known from three separate coelurosaurian clades: Oviraptorosauria, Therizinosauroidea, and Ornithomimosauria. Although these taxa span the Early and Late Cretaceous, they are all discussed here for simplicity.

The enormous oviraptorosaur Gigantoraptor, from the Iren Dabasu Formation of Inner Mongolia, may have reached masses of 1400 kilograms (Xu et al., 2007). Like most other oviraptorosaurs, Giganotoraptor had a short, deep, and toothless skull fronted by a beak, which was likely used to crop vegetation or crush small invertebrates and/or eggs. It lived alongside the tyrannosauroid Alectrosaurus, which was approximately the same size but likely a more traditional predator.

The therizinosauroid Suzhousaurus, from the AptianAlbian (Early Cretaceous) Xinminpu Group of Gansu, is one of the largest members of this bizarre group of derived theropods (Li et al., 2007, 2008). The femur of one specimen is 84 centimeters long, about $20 \%$ shorter than average-sized Allosaurus femora (Madsen, 1976; Christiansen, 1999). Only parts of the postcranial skeleton are known, and skull bones have yet to be discovered. However, other therizinosauroids have unusual skulls with leaf-shaped teeth, similar in many ways to those of "prosauropod" herbivores. Other features of the skull, including its general shape, are also similar to "prosauropods," and give further evidence that these aberrant theropods were primarily herbivorous (Clark et al, 2004). Other Asian therizinosauroids, such as Therizinosaurus cheloniformis from the Late Cretaceous of Mongolia, also achieved large body size. Most remarkably, the manual claws of this species may have approached 50-100 centimeters in length (Maleev, 1954; Barsbold, 1976). Un- 
fortunately, many of these taxa are also fragmentary, and there is no evidence that any of them were primarily carnivorous.

Several Asian ornithomimosaurs attained large size, including the Early Cretaceous Beishanlong and the Late Cretaceous Gallimimus and Deinocheirus. Beishanlong is known from several postcranial bones from the Aptian-Albian Xinminpu Group of Gansu (Makovicky et al., 2010). Its femur is 66 centimeters long, resulting in a body mass estimate of approximately 626 kilograms. A similar size was reached by Gallimimus, one of the best known ornithomimosaurs, which is commonly found in the Maastrichtian Nemegt Formation (Osmólska et al., 1972; Makovicky et al., 2004). Perhaps the largest ornithomimosaur of all was the enigmatic Deinocheirus, another Maastrichtian Nemegt taxa that is only known from a single fragmentary specimen, including a pair of enormous forelimbs that measure approximately $2.4 \mathrm{me}-$ ters in length and are capped by 25 -cm-long claws (Osmólska and Roniewicz, 1970). Some authors estimate that Deinocheirus may have been up to 9000 kilograms in mass (Valkenburgh and Molnar, 2002), although further specimens are clearly needed to better understand this puzzling animal. Cranial material remains unknown for Deinocheirus and Beishanlong, but the skull of Gallimimus is similar to that of most other ornithomimosaurs in lacking teeth and possessing a beak at the front of the jaws. This skull shape, along with the possession of gastric mills in the gut, suggests that ornithomimosaurs were herbivores or possibly suspension feeders that lived near the water's edge (Norell et al., 2001; Barrett, 2005).

Finally, among more traditional predatory coelurosaurs, there are few obvious examples of non-tyrannosaurid taxa obtaining large body size during the Late Cretaceous of Asia. The dromaeosaurid Achillobator from the Late Cretaceous of Mongolia (Hicks et al., 1999) may have reached a body mass of approximately 350 kilograms (Perle et al., 1999; Turner et al., 2007), but other dromaeosaurs, as well as troodontids, alvarezsaurids, and bona fide avians, were small-bodied animals that rarely reached sizes larger than an average man.

\subsection{Paleobiogeography, Evolution, and Faunal Change}

The large-bodied theropod fossil record from the Campanian and Maastrichtian of Asia has long been among the best studied and most complete from anywhere in the world. Along with faunas from western North America, and a lesser extent those from South America and Europe, the Asian fossils have helped researchers understand the evolution of dinosaurs during the waning years of the Mesozoic (Weishampel et al., 2004). In short, they represent some of the best, and only, evidence of dinosaur communities that lived within a few million years of the catastrophic end-Cretaceous mass extinction. These fossils reveal two important patterns of large-bodied theropod evolution.

First, only tyrannosaurids are known to have occupied the large predator niche during the terminal Cretaceous of Asia. This is in contrast to earlier time periods, when multiple groups of large predators, such as the spinosaurids and carcharodontosaurians of the Early Cretaceous, obtained large body size. Such depauperate faunas, in which only a single clade filled the large predator role, are also seen in the Campanian and Maastrichtian of North America, which was also dominated by tyrannosaurids (Holtz, 2004; Weishampel et al., 2004). Although comparatively little is known about the terminal Cretaceous faunas in Africa, Europe, and South America, the few Campanian and Maastrichtian dinosaur fossil sites on these landmasses offer no evidence for multiple groups of large predators (Weishampel et al., 2004). One exception may be South America, as new evidence suggests that mid-tolarge-sized allosauroids persisted alongside abelisaurid ceratosaurs in the large predator niche until late into the Cretaceous (Benson et al., 2010). However, only one allosauroid fossil from the Maastrichtian of South America has been described (Orkoraptor) and its age is suspect (Novas et al., 2008). Therefore, it seems likely that depauperate keystone predator faunas, exemplified by only a single large predator or multiple large predators of a single restricted clade, may have characterized terminal Cretaceous dinosaur communities globally.

Second, the large tyrannosaurid predators of Late Cretaceous Asia are closely related to North American taxa. Indeed, tyrannosaurids are only known from North America and Asia, and large-bodied forms are only known from the final 20 million years of the Cretaceous (Currie, 2000; Holtz, 2004; Brusatte et al., 2009a). The more inclusive tyrannosauroid clade, which originated approximately 100 million years before Tarbosaurus was dominating Maastrichtian ecosystems in Asia, is also known from Europe, but has yet to be recorded in Africa, Antarctica, Australia, India, Madagascar, or South America. Therefore, all current evidence suggests that the tyrannosauroid clade was solely a Laurasian group, restricted to the northern continents. Tyrannosaurids are one of many dinosaur groups that exhibited trans-Laurasian (or at least Asian and North American) distributions during the Late Cretaceous; others include ceratopsians, hadrosaurs, and pachycephalosaurs (e.g., Sereno, 2000; Upchurch et al., 2002). This repeated biogeographic pattern is not surprising, as by the 
Late Cretaceous the configuration of the major continents was beginning to resemble the modern situation, in which northern and southern landmasses are largely separated by oceanic barriers. In sum, Asian large theropods are some of the primary evidence used to support hypotheses of Late Cretaceous dinosaur provincialism.

Large derived tyrannosaurids are still unknown from Europe but this is potentially due to sampling bias, since Campanian-Maastrichtian fossil sites are rare on this landmass, and large theropods are particularly uncommon discoveries (Weishampel et al., 2004). However, great uncertainty remains. Asia was separated from Europe (which was largely a series of islands) by the Turgai Sea during the Late Cretaceous, from the Cenomanian or Turonian onwards, and it is possible that this seaway formed a barrier to faunal interchange (Cox, 1974; Smith et al., 1994). Small theropods with European and Asian distributions, such as compsognathids and ornithomimosaurs, suggest that such interchange did occur during the Late Jurassic-Early Cretaceous (e.g., Ji et al., 2003). Unfortunately, the poor Campanian-Maastrichtian European record makes it difficult to assess if and when this interchange ceased, and whether Asian faunas were more similar to those from North America or Europe during the waning years of the Cretaceous. Evidence from other dinosaur clades suggests that European and North American faunas may have been most similar to each other during the Late Cretaceous (Upchurch et al., 2002), and mammal fossils have been used to argue for North American-European high latitude dispersal during this time (Martin et al., 2005). However, it must be kept in mind that western and eastern North America were separated by the Western Interior Seaway during the Late Cretaceous, and thus it is plausible that western North America shared taxa with Asia and eastern North America with Europe.

\section{Discussion and conclusions}

Large-bodied theropods had a long history in Asia and were present from at least the early Middle Jurassic until the very end of the Cretaceous, a time span of at least 100 million years. During this time, the evolution of these dinosaur apex predators was far from static. The oldest large theropods of Asia, from the Middle Jurassic, belonged to largely endemic clades of basal tetanuran theropods. Endemic clades are known from other areas at this time, and most likely reflect provincialism that developed soon after the initial fragmentation of Pangea. However, as Asia was reconnected to other landmasses during the Late Jurassic-Early Cretaceous, large theropod faunas of this time developed a more cosmopolitan flavor. The major apex predators of this time, the Late Jurassic sinraptorids and the Early-mid Cretaceous carchardontosaurians and spinosaurids, had close relatives on other landmasses. In particular, it seems that Early-mid Cretaceous dinosaur faunas as a whole were essentially cosmopolitan, despite the continued separation of Pangea into various landmasses. By the terminal Cretaceous, however, more derived bird-like theropods had assumed the large predator role in Asia. These animals, most prominently the colossal tyrannosaurids, were closely related to North American taxa, and along with other dinosaur clades indicate that terrestrial vertebrate faunas were provincial at this time. Most importantly, Asia and North America shared taxa, including tyrannosaurids, to the exclusion of the southern continents, a pattern that surely reflected the now great separation between the former components of Laurasia and Gondwana.

Our understanding of Asian large theropod evolution can be summarized in two general statements. First, the biogeographic affinities of large Asian theropods over time was intimately related to physical geography, especially the slow fragmentation of Pangea and the establishment and severing of various connections with other landmasses. Second, over time progressively more derived theropod clades evolved large body size and occupied the apex predator niche, beginning with basal tetanurans in the Middle Jurassic, continuing with "intermediate" spinosaurids, sinraptorids, and carcharodontosaurians in the Late Jurassic-mid Cretaceous, and ending with coelurosaurs in the Campanian-Maastrichtian. However, it is possible, and even probable, that these patterns will be challenged by future fossil discoveries. Indeed, much of this picture has been pieced together over the past two decades, especially with the discovery of new taxa in China, Mongolia, Japan, and Southeast Asia and the redescription of long-neglected specimens. Dinosaur fieldwork is active across the Asian continent, and the potential for future discoveries is tantalizing.

\section{Note Added in Proof:}

After this paper was accepted, Benson et al. (2010) described a theropod pubis from the Early Cretaceous of Australia as pertaining to a tyrannosauroid. Therefore, it is likely that tyrannosauroids were present in the southern continents early in their evolution, but there still is no indication that they inhabited anywhere but the northern continents during the Late Cretaceous. (Benson, R.B.J., Barrett, P.M., Rich, T.H., Vickers-Rich, P. (2010): A southern tyrant reptile. Science, 327: 1613). 


\section{Acknowledgements}

We thank numerous curators for access to specimens in their care, most importantly Magdalena Borsuk-Bialynicka, Sandra Chapman, Steve Hutt, Angela Milner, Mark Norell, Paul Sereno, and Zhao Xijin. We thank Mark Norell for comments on an earlier draft of this paper, Albert Prieto-Marquez for translating the abstract and figure captions into Spanish, and Brett Booth for the skull reconstruction of Shaochilong. We are also grateful for the helpful comments of the reviewers, Peter Makovicky and Thomas Holtz. SLB especially thanks Zhao Xijin for inspiring his interest in Chinese theropods and inviting him to study Monolophosaurus, as well as Mark Norell and Paul Sereno for bringing him on research trips to China and Philip Currie for his advice and collaboration. SLB is supported by a National Science Foundation Graduate Research Fellowship and by the American Museum of Natural History. His visit to the Mesozoic Terrestrial Ecosystems conference was generously supported by an MTE student scholarship. XX is supported by the Chinese Academy of Sciences and the Natural Science Foundation of China.

\section{References}

Allain, R. (2001): Redescription de Streptospondylus altdorfensis, le dinosaure théropode de Curvier, du Jurassique de Normandie. Geodiversitas, 23: 349-367.

Allain, R. (2002): Discovery of megalosaur (Dinosauria, Theropoda) in the middle Bathonian of Normandy (France) and its implications for the phylogeny of basal Tetanurae. Journal of Vertebrate Paleontology, 22: 548-563. http://dx.doi. org/10.1671/0272-4634(2002)022[0548:DOMDTI]2.0. $\mathrm{CO} ; 2$

Allain, R. (2005): The postcranial anatomy of the megalosaur Dubreuillosaurus valesdunensis (Dinosauria, Theropoda) from the Middle Jurassic of Normandy, France. Journal of Vertebrate Paleontology, 25: 850-858. http://dx.doi.org/10.1671/02724634(2005)025[0850:TPAOTM]2.0.CO;2

Allain, R., Chure, D.J. (2002): Poekilopleuron bucklandii, the theropod dinosaur from the Middle Jurassic (Bathonian) of Normandy. Palaeontology, 45: 1107-1121. http://dx.doi. org/10.1111/1475-4983.00277

Anderson, J.F., Hall-Martin A., Russell, D.A. (1985): Long-bone circumference and weight in mammals, birds and dinosaurs. Zoological Journal of the Linnean Society of London, 207: 53-61.

Azuma, Y., Currie, P.J. (2000): A new carnosaur (Dinosauria: Theropoda) from the Lower Cretaceous of Japan. Canadian Journal of Earth Sciences, 37: 1735-1753. http://dx.doi. org/10.1139/cjes-37-12-1735

Barrett, P.M. (2005): The diet of ostrich dinosaurs (Theropoda: Ornithomimosauria). Palaeontology, 48: 347-358. http://dx.doi. org/10.1111/j.1475-4983.2005.00448.x

Barrett, P.M., Hasegawa, Y., Manabe, M., Isaji, S., Matsuoka, H. (2002): Sauropod dinosaurs from the Lower Cretaceous of eastern Asia: taxonomic and biogeographical implications. Pal- aeontology, 45: 1197-1217. http://dx.doi.org/10.1111/1475$\underline{4983.00282}$

Barsbold, R. (1976): New data on Therizinosaurus (Therizinosauridae, Theropoda). Trudy, Sovmestnaâ Sovetsko-Mongol'skaâ paleontologičeskaâ kspediciâ, 3: 76-92.

Benson, R.B.J. (2008): New information on Stokesosaurus, a tyrannosauroid (Dinosauria: Theropoda) from North America and the United Kingdom. Journal of Vertebrate Paleontology, 28: 732750. http://dx.doi.org/10.1671/0272-4634(2008)28[732:NIO SAT]2.0.CO;2

Benson, R.B.J. (2009a): An assessment of variability in theropod dinosaur remains from the Bathonian (Middle Jurassic) of Stonesfield and New Park Quarry, UK and taxonomic implications for Megalosaurus bucklandii and Iliosuchus incognitos. Palaeontology, 52: 857-877.

Benson, R.B.J. (2009b): A redescription of 'Megalosaurus' hesperis (Dinosauria, Theropoda) from the Inferior Oolite (Bajocian, Middle Jurassic) of Dorset, united Kingdom. Zootaxa, 1931: 57-67.

Benson, R.B.J. (2010): A description of Megalosaurus bucklandii (Dinosauria: Theropoda) from the Bathonian of the United Kingdom and the relationships of Middle Jurassic theropods. Zoological Journal of the Linnean Society, 158: 882-935.

Benson, R.B.J., Xu, X. (2008): The anatomy and systematic position of the theropod dinosaur Chilantaisaurus tashuikouensis $\mathrm{Hu}, 1964$ from the Early Cretaceous of Alanshan, People's Republic of China. Geological Magazine, 145: 778-789. http:// dx.doi.org/10.1017/S0016756808005475

Benson, R.B.J., Barrett, P.M., Powell, H.P., Norman, D.B. (2008): The taxonomic status of Megalosarus bucklandii (Dinosauria, Theropoda) from the Middle Jurassic of Oxfordshire, UK. Palaeontology, 52: 419-424. http://dx.doi.org/10.1111/j.14754983.2008.00751.x

Benson, R.B.J., Carrano, M.T., Brusatte, S.L. (2010): A new clade of archaic large-bodied predatory dinosaurs (Theropoda: Allosauroidea) that survived to the latest Mesozoic. Naturwissenschaften, 97: 71-78. http://dx.doi.org/10.1007/s00114-0090614-x

Brusatte, S.L., Benson, R.B.J, Hutt, S. (2008): The osteology of Neovenator salerii (Dinosauria: Theropoda): from the Wealden Group (Barremian) of the Isle of Wight. Monograph of the Palaeontographical Society, 162(631): 1-166.

Brusatte, S.L., Benson, R.B.J, Currie, P.J., Zhao, X.-J. (2010a): The skull of Monolophosaurus jiangi (Dinosauria: Theropoda) and its implications for early theropod phylogeny and evolution. Zoological Journal of the Linnean Society, 157: 573-607. http:// dx.doi.org/10.1111/j.1096-3642.2009.00563.x

Brusatte, S.L., Benson, R.B.J., Chure, D.J., Xu, X., Sullivan, C., Hone, D.E.W. (2009a): The first definitive carcharodontosaurid (Dinosauria: Theropoda) from Asia and the delayed ascent of tyrannosaurids. Naturwissenschaften, 96: 1051-1058. http:// dx.doi.org/10.1007/s00114-009-0565-2

Brusatte, S.L., Carr, T.D., Erickson, G.M., Bever, G.S., Norell, M.A. (2009b): A long-snouted, multi-horned tyrannosaurid from the Late Cretaceous of Mongolia. Proceedings of the $\mathrm{Na}$ tional Academy of Sciences (USA), 106: 17261-17266.

Brusatte, S.L., Chure, D.J., Benson, R.B.J., Xu, X. (2010b): The osteology of Shaochilong maortuensis, a carcharodontosaurid (Dinosauria: Theropoda) from the Late Cretaceous of Asia. Zootaxa, 2334: 1-46.

Brusatte, S.L., Sereno, P.C. (2008): Phylogeny of Allosauroidea (Dinosauria: Theropoda): comparative analysis and resolution. 
Journal of Systematic Palaeontology, 6: 155-182. http://dx.doi. org/10.1017/S1477201907002404

Buffetaut, E., Ingavat, R. (1986): Unusual theropod dinosaur teeth from the Upper Jurassic of Phu Wiang, northeastern Thailand. Revue de Paléobiologie, 5: 217-220.

Buffetaut, E., Suteethorn, V., Tong, H. (1996): The earliest known tyrannosaur from the Lower Cretaceous of Thailand. Nature, 381: 689-691. http://dx.doi.org/10.1038/381689a0

Buffetaut, E., Suteethorn, V. (1999): The dinosaur fauna of the Sao Khua Formation of Thailand and the beginning of the Cretaceous radiation of dinosaurs in Asia. Palaeogeography, Palaeoclimatology, Palaeoecology, 150: 13-23. http://dx.doi. org/10.1016/S0031-0182(99)00004-8

Buffetaut, E., Suteethorn, V. (2007): A sinraptorid theropod (Dinosauria: Saurischia) from the Phu Kradung Formation of northeastern Thailand. Bulletin de la Société géologique de France, 178: 497-502 http://dx.doi.org/10.2113/gssgfbull.178.6.497

Buffetaut, E., Suteethorn, V., Tong, H., Amiot, R. (2008): An Early Cretaceous spinosaurid theropod from southern China. Geological Magazine, 145: 745-748. http://dx.doi.org/10.1017/ $\underline{\mathrm{S} 0016756808005360}$

Carr, T.D. (1999): Craniofacial ontogeny in Tyrannosauridae (Dinosauria, Theropoda). Journal of Vertebrate Paleontology, 19: 497-520. http://dx.doi.org/10.1080/02724634.1999.10011161

Carr, T.D., Williamson, T.E. (2004): Diversity of late Maastrichtian Tyrannosauridae (Dinosauria: Theropoda) from western North America. Zoological Journal of the Linnean Society, 142: 479$523 \mathrm{http} / / / \mathrm{dx}$. doi.org/10.1111/j.1096-3642.2004.00130.x

Chen, P.-J., Dong, Z.-M., Zhen, S.-N. (1998): An exceptionally well-preserved theropod dinosaur from the Yixian Formation of China. Nature, 391: 147-152.

Chen, Z., Li, Z.X., Powell, C.M., Balme, B.E. (1993): Paleomagnetism of the Brewer Conglomerate in central Australia, and fact movement of Gondwanaland during the Late Devonian. Geophysical Journal International, 115: 564-574. http://dx.doi. org/10.1111/j.1365-246X.1993.tb01207.x

Christiansen, P. (1999): Long bone scaling and limb posture in non-avian theropods: evidence for differential allometry. Journal of Vertebrate Paleontology, 19: 666-680. http://dx.doi.org/ $\underline{10.1080 / 02724634.1999 .10011180}$

Christiansen, P., Fariña, R.A. (2004): Mass prediction in theropod dinosaurs. Historical Biology, 16: 85-92. http://dx.doi.org/10.1 080/08912960412331284313

Chure, D.J. (1998): "Chilantaisaurus" maortuensis, a large maniraptoran theropod from the Early Cretaceous (Albian) of Nei Mongol, PRC. Journal of Vertebrate Paleontology, 18: 33A-34A.

Chure, D.J. (2000): A new species of Allosaurus from the Morrison Formation of Dinosaur National Monument (UT-CO) and a revision of the theropod family Allosauridae. Unpublished Ph.D. dissertation, Columbia University, New York.

Clark, J.M., Maryanska, T., Barsbold, R. (2004): Therizinosauroidea. In: D.B. Weishampel, P. Dodson, P., H. Osmólska (eds.), The Dinosauria, $2^{\text {nd }}$ edn. University of California Press, Berkeley, 151-164.

Cox, C.B. (1974): Vertebrate palaeodistributional patterns and continental drift. Journal of Biogeography, 1: 75-94. http:// dx.doi.org/10.2307/3037956

Currie, P.J. (2000): Theropods from the Cretaceous of Mongolia. In: M.J. Benton, M.A. Shishkin, D.M. Unwin, E.N. Kurochkin (ed.), The Age of Dinosaurs in Russia and Mongolia. Cambridge University Press, Cambridge, 434-455.
Currie, P.J. (2003): Cranial anatomy of tyrannosaurid dinosaurs from the Late Cretaceous of Alberta, Canada. Acta Palaeontologica Polonica, 48: 191-226.

Currie, P.J., Hurum, J.H., Sabath, K. (2003): Skull structure and evolution in tyrannosaurid dinosaurs. Acta Palaeontologica Polonica, 48: 227-234.

Currie, P.J., Azuma, Y. (2006): New specimens, including a growth series, of Fukuiraptor (Dinosauria, Theropoda): from the Lower Cretaceous Kitadani Quarry of Japan. Journal of the Paleontological Society of Korea, 22: 173-193.

Dashzeveg, D., Novacek, M.J., Norell, M.A., Clark, J.M., Chiappe, L.M., Davidson, A., McKenna, M.C., Dingus, L., Swisher, C., Perle, A. (1995): Extraordinary preservation in a new vertebrate assemblage from the Late Cretaceous of Mongolia. Nature, 374: 446-449. http://dx.doi.org/10.1038/374446a0

Dong, Z.-M. (1973): Dinosaurs from Wuerho. Memoirs of the Institute of Vertebrate Paleontology and Paleoanthropology Academica Sinica, 11: 45-52.

Dong, Z.-M. (1984): [A new theropod dinosaur from the Middle Jurassic of Sichuan Basin]. Vertebrata PalAsiatica, 22: 213-218 [in Chinese with English abstract].

Dong, Z.-M., Tang, Z. (1985): [A new mid-Jurassic theropod (Gasosaurus constructus gen. et sp. nov.) from Dashanpu, Zigong, Sichuan Province, China]. Vertebrata PalAsiatica, 23: 77-83 [inChinese with English summary].

Dong, Z.-M., Chang, Y., Li, X., Zhou, S.-W. (1978): [Note on a new carnosaur (Yangchuanosaurus shangyouensis gen. et sp. nov.) from the Jurassic of Yangchuan District, Szechuan Province]. Kexue Tongbao, 23: 298-302 [in Chinese].

Dong, Z-M., Zhou, S., Zhang, Y. (1983): [The dinosaurian remains of Sichuan Basin, China]. Palaeontologica Sinica (new series C), 23: 1-145 [in Chinese with English summary].

Erickson, G.M., Olson, K.H. (1996): Bite marks attributable to Tyrannosaurus rex: preliminary description and implications. Journal of Vertebrate Paleontology, 16: 175-178. http://dx.doi. org/10.1080/02724634.1996.10011297

Erickson, G.M., Van Kirk, S.D., Su, J., Levenston, M.E., Caler, W.E., Carter, D.R. (1996): Bite-force estimation for Tyrannosaurus rex from tooth-marked bones. Nature, 382: 706-708. http://dx.doi.org/10.1038/382706a0

Gao, Y. (1992): [Yangchuanosaurus hepingensis-a new species of carnosaur from Zigong, Sichuan]. Vertebrata PalAsiatica, 30: 313-324 [in Chinee with English summary].

Gao, Y. (1993): [A new species of Szechuanosaurus from the Middle Jurassic of Dashanpu, Zigong, Sichuan]. Vertebrata PalAsiatica, 31: 308-314 [in Chinese with English summary].

Gao, Y. (1999): [A complete carnosaur skeleton from Zigong, Sichuan: Yangchuanosaurus hepingensis]. Sichuan Science and Technology Press, Chengdu 1-100 [in Chinese with English summary].

Gheerbrant, E., Rage, J.-C. (2006): Paleobiogeography of Africa: How distinct from Gondwana and Laurasia? Palaeogeographhy, Palaeoclimatology, Palaeoecology, 241: 224-246. http:// dx.doi.org/10.1016/j.palaeo.2006.03.016

Gilmore, C.W. (1933): On the dinosaurian fauna of the Iren Dabasu Formation. Bulletin of the American Museum of Natural History, 67: 23-78.

Harris, J. D. (1998): A reanalysis of Acrocanthosaurus atokensis, its phylogenetic status, and Paleobiogeographic implications, based on a new specimen from Texas. New Mexico Museum of Natural History and Science Bulletin, 13: 1-75.

Hasegawa, Y., Buffetaut, E., Manabe, M., Takakuwa, Y. (2003): A 
possible pinosaurid tooth from the Sebayashi Formation (Lower Cretaceous), Gunma, Japan. Bulletin of the Gunma Museum of Natural History, 7: 1-5.

He, H.Y., Wang, X.L., Zhou, Z.H.,Jin, F., Wang, F., Yang, L.K., Ding, X., Boven, A., Zhu, R.X. (2006): ${ }^{40} \mathrm{Ar} /{ }^{39} \mathrm{Ar}$ dating of Lujiatun Bed (Jehol Group) in Liaoning, northeastern China, Geophysical Research Letters, 33,: L04303.

He, X. (1984): [The Vertebrate Fossils of Sichuan]. Sichuan Scientific and Technological Publishing House, Chengdu 1-168 [in Chinese].

Hicks, J.F., Brinkman, D.L., Nichols, D.J., Watabe, M. (1999): Paleomagnetic and palynological analyses of Albian to Santonian strata at Bayn Shireh, Burkhant, and Khuren Dukh, eastern Gobi Desert, Mongolia. Cretaceous Research, 20: 829-850. http://dx.doi.org/10.1006/cres.1999.0188

Hocknull, S.A., White, M.A., Tischler, T.R., Cook, A.G., Calleja, N.D., Sloan, T., Elliott, D.A. (2009): New mid-Cretaceous (latest Albian) dinosaurs from Winton, Queensland, Australia. PLoS ONE, 4(7): 1-51.

Holtz, T.R. (2001): The phylogeny and taxonomy of the Tyrannosauridae. In: K. Carpenter, D. Tanke (eds.) Mesozoic Vertebrate Life. Indiana University Press, Bloomington, Indiana.

Holtz, T.R. (2004): Tyrannosauroidea. In: D.B. Weishampel, P. Dodson, P., H. Osmólska (eds.), The Dinosauria, $2^{\text {nd }}$ edn. University of California Press, Berkeley, 111-136.

Holtz, T.R., Molnar, R.E., Currie P.J. (2004): Basal Tetanurae. In: D.B. Weishampel, P. Dodson, P., H. Osmólska (ed.), The Dinosauria, $2^{\text {nd }}$ edn. University of California Press, Berkeley, 71-110.

Hone, D.W.E, Xu, X., Wang, D.A. (2010): A probable baryonychine tooth from the Late Cretaceous of Henan Province, China. Vertebrata PalAsiatica, 48: 19-26.

Hu, D., Hou, L., Zhang, L., Xu, X. (2009): A pre-Archaeopteryx troodontid theropod from China with long feathers on the metatarsus. Nature, 461: 640-643. http://dx.doi.org/10.1038/nature08322

Hu, S. (1993): A short report on the occurrence of Dilophosaurus from Jinning County, Yunnan Province. Vertebrata PalAsiatica, 31: 65-69.

Hu, S.-Y. (1964): Carnosaurian remains from Alashan, Inner Mongolia. Vertebrata Pal Asiatica, 8: 42-63.

Hurum, J., Currie, P.J. (2000): The crushing bite of tyrannosaurids. Journal of Vertebrate Paleontology, 29: 619-621. http://dx.doi. org/10.1671/0272-4634(2000)020[0619:TCBOT]2.0.CO;2

Hurum, J., Sabath, K. (2003): Giant theropod dinosaurs from Asia and North America: skulls of Tarbosaurus bataar and Tyrannosaurus rex compared. Acta Palaeontologica Polonica, 48: 161-190.

Huxley, T.H. (1868): On the animals which are most nearly intermediate between the birds and reptiles. Geological Magazine, 5: 357-365.

Ji, Q., Currie, P.J., Norell, M.A., Ji, S.-A. (1998): Two feathered dinosaurs from northeastern China. Nature, 393: 753-761.

Ji, Q., Norell, M.A., Makovicky, P.J., Gao, K.-Q., Ji, S.-A., Yuan, C. (2003): An early ostrich dinosaur and implications for ornithomimosaur phylogeny. American Museum Novitates, 3420: 1-19. http://dx.doi.org/10.1206/0003-0082(2003)420<0001:AEO DAI $>2.0 . \mathrm{CO} ; 2$

Ji, Q., Ji, S.-A., Zhang, L.-J. (2009): First large tyrannosauroid theropod from the Early Cretaceous Jehol Biota in northeastern China. Geological Bulletin of China, 28: 1369-1374.

Kobayashi, Y., Azuma, Y. (2003): A new iguanodintian (Dinosauria: Ornithopoda) from the Lower Cretaceous Kitadani Forma- tion of Fukui Prefecture, Japan. Journal of Vertebrate Paleontology, 23: 166-175.

Kobayashi, Y., Lu, J.-C. (2003): A new ornithomimid dinosaur with gregarious habits from the Late Cretaceous of China. Acta Palaeontologica Polonica, 48: 235-259.

Kobayashi, Y., Lu, J.-C., Dong, Z.-M., Barsbold, R., Azuma, Y. (1999): Herbivorous diet in an ornithomimid dinosaur. Nature, 402: 480-481.

Kurzanov, S.M. (1976): A new carnosaur from the Late Cretaceous of Nogon-Tsav, Mongolia. The Joint Soviet-Mongolian Paleontological Expedition Transactions, 3: 93-104.

Lamanna, M.C., Smith, J.B., You, H., Holtz, T.R., Dodson, P. (1998): A reassessment of the Chinese theropod dinosaur Dilophosaurus sinensis. Journal of Vertebrate Paleontology, 18: 57A.

Li, D., Peng, C., You, H., Lamanna, M.C., Harris, J.D., Lacovara, K.J., Zhang, J. (2007): A large therizinosauroid (Dinosauria: Theropoda) from the Early Cretaceous of northwestern China. Acta Geologica Sinica, 81: 539-549.

Li, D., Zhang, J.-P., You, H.-L., (2008): A new specimen of Suzhousaurus megatherioides (Dinosauria: Therizinosauroidea) from the Early Cretaceous of northwestern China. Canadian Journal of Earth Sciences, 45: 769-779.

Li, D., Norell M.A., Gao, K., Smith, N.D., Makovicky, P.J. (2010): A longirostrine tyrannosauroid from the Early Cretaceous of China. Proceedings of the Royal Society Series B, 277: 183-190. http://dx.doi.org/10.1098/rspb.2009.0249

Li, F., Peng, G., Ye, Y., Jiang, S., Huang, D. (2009): A new carnosaur from the Late Jurassic of Qianwei, Sichuan, China. Acta Geologica Sinica, 83: 1203-1213.

Loope, D.B., Dingus, L., Swisher, C.C., Minjin, C. (1998): Life and death in a Late Cretaceous dune field, Nemegt basin, Mongolia. Geology, 26: 27-30. http://dx.doi.org/10.1130/00917613(1998)026<0027:LADIAL $>2.3 . \mathrm{CO} ; 2$

Ohashi, T., Barrett, P.M. (2009): A new ornithischian dinosaur from the Lower Cretaceous Kuwajima Formation of Japan. Journal of Vertebrate Paleontology, 29: 748-757. http://dx.doi. org/10.1671/039.029.0306

Mader, B. J., and Bradley, R. L. (1989): A redescription and revised diagnosis of the syntypes of the Mongolian tyrannosaur Alectrosaurus olseni. Journal of Vertebrate Paleontology, 9: 4155. http://dx.doi.org/10.1080/02724634.1989.10011737

Madsen, J.H. (1974): A new theropod dinosaur from the Upper Jurassic of Utah. Journal of Paleontology, 48: 27-31.

Madsen, J.H. (1976): Allosaurus fragilis: a revised osteology. Utah Geological Survey Bulletin, 109: 1-163.

Makovicky, P.J., Kobayashi, Y., Currie, P.J. (2004): Ornithomimosauria. In: D.B. Weishampel, P. Dodson, P., H. Osmólska (eds.), The Dinosauria, $2^{\text {nd }}$ edn. University of California Press, Berkeley, 137-150.

Makovicky, P.J., Li, D., Gao, K., Lewin, M., Erickson. G.M., Norell, M.A. (2010): A giant ornithomimosaur from the Early Cretaceous of China. Proceedings of the Royal Society Series B, 277: 191-198. http://dx.doi.org/10.1098/rspb.2009.0236

Maleev, E.A. (1954): New turtle-like reptile in Mongolia. Priroda, 1954(3): 106-108.

Maleev, E.A. (1955): New carnivorous dinosaurs from the Upper Cretaceous of Mongolia. Doklady Akademica Nauk CCCP, 104: 779-782.

Maleev, E.A. (1974): Gigantic carnosaurs of the family Tyrannosauridae. Sovmestnaia Sovestsko-Mongol'skaia Paleontologicheskaia Ekspeditsiia Trudy, 1: 132-191.

Martin, J.E., Case, J.A., Jagt, J.W.M., Schulp, A.S., Mulder, E.W.A. 
(2005): A new European marsupial indicates a Late Cretaceous high-latitude transatlantic dispersal route. Journal of Mammalian Evolution, 12: 495-510. http://dx.doi.org/10.1007/s10914005-7330-x

Mateus, O. (1998): Lourinhanosaurus antunesi, a new Upper Jurassic allosauroid (Dinosauria: Theropoda) from Lourinhã, Portugal. Memórias da Academia de Ciências de Lisboa, 37: 111-124.

Metcalfe, I. (2006): Palaeozoic and Mesozoic tectonic evolution and palaeogeography of East Asian crustal fragments: the Korean Peninsula in context. Gondwana Research, 9: 24-46.

Milner, A., Buffetaut, E., Suteethorn, V. (2007): A tall-spined spinosaurid theropod from Thailand and the biogeography of spinosaurs. Journal of Vertebrate Paleontology, 27; 118A.

Molnar, R.E., Kurzanov, S.M., Dong, Z. (1990): Carnosauria. In: D.B. Weishampel, P. Dodson, P., H. Osmólska (ed.), The Dinosauria. University of California Press, Berkeley, 169-209.

Murphy, M.A., Yin, A., Harrison, T.M., Durr, S.B., Chen, Z., Ryerson, F.J., Kidd, W.S.F., Wang, X., Zhou, X. (1997): Did the Indo-Asian collision alone create the Tibetan plateau? Geology, 25: 719-722. http://dx.doi.org/10.1130/00917613(1997)025<0719:DTIACA $>2.3 . C O ; 2$

Norell, M.A., Makovicky, P.J., Currie, P.J. (2001): The beaks of ostrich dinosaurs. Nature, 412: 873-874.

Norell, M.A., Xu, X. (2005): Feathered dinosaurs. Annual Review of Earth and Planetary Sciences, 33: 277-299. http://dx.doi. org/10.1146/annurev.earth.33.092203.122511

Norman, D.B. (1998): On Asian ornithopods (Dinosauria: Ornithischia). 3. A new species of iguanodontid dinosaur. Zoological Journal of the Linnean Society, 122: 291-348. http://dx.doi. org/10.1006/zjls.1997.0122

Novas, F.E., Ezcurra, M.D., Lecuona, A. (2008): Orkoraptor burkei nov. gen. et sp., a large theropod from the Maastrichtian Pari Aike Formation, Southern Patagonia, Argentina. Cretaceous Research, 29: 468-480. http://dx.doi.org/10.1016/j. cretres.2008.01.001

Osmólska, H., Roniewicz, E., Barsbold, R. (1972): A new dinosaur, Gallimimus bullatus n. gen., n. sp. (Ornithomimidae) from the Upper Cretaceous of Mongolia. Palaeontologia Polonica, 27: 103-143

Osmólska, H., Roniewicz, R. (1970): Deinocheiridae, a new family of theropod dinosaurs. Palaeontologica Polonica, 21: 5-19.

Ostrom, J.H. (1969): A new theropod dinosaur from the Lower Cretaceous of Montana. Postilla, 128: 1-17.

Peng, G.Z., Ye, Y., Gao, Y.H., Shu, C.K., Jiang, S. (2005): Jurassic dinosaur faunas in Zigong. Sichuan People's Publishing House, $236 \mathrm{pp}$.

Perle, A. (1977): On the first finding of Alectrosaurus (Tyrannosauridae, Theropoda) in the Late Cretaceous of Mongolia. Problems of Mongolian Geology, 3: 104-113.

Perle, A., Norell, M.A., Clark, J. (1999): A new maniraptoran theropod - Achillobator giganticus (Dromaeosauridae) - from the Upper Cretaceous of Burkhant, Mongolia. Contributions of the Mongolian-American Paleontological Project, 101: 1-105.

Prum, R.O., Brush, A.H. (2002): The evolutionary origin and diversification of feathers. Quarterly Review of Biology, 77: 261-296. http://dx.doi.org/10.1086/341993

Racey, A., Love, M.A., Canham, A.C., Goodall, J.G.S., Polachan, S., Jones, P.D. (1996): Stratigraphy and reservoir potential of the Mesozoic Khorat Group, NE Thailand. Part 1: Stratigraphy and sedimentary evolution. Journal of Petroleum Geology, 19: 5-40. http://dx.doi.org/10.1111/j.1747-5457.1996.tb00511.x
Rauhut, O.W.M. (2003a): The interrelationships and evolution of basal theropod dinosaurs. Special Papers in Palaeontology, 69: 1-213.

Rauhut, O.W.M. (2003b): A tyrannosauroid dinosaur from the Upper Jurassic of Portugal. Palaeontology, 46: 903-910. http:// dx.doi.org/10.1111/1475-4983.00325

Rauhut, O.W.M., Xu, X. (2005): The small theropod dinosaurs Tugulusaurus and Phaedrolosaurus from the Early Cretaceous of Xinjiang, China. Journal of Vertebrate Paleontology, 25: 107-118. http://dx.doi.org/10.1671/02724634(2005)025[0107:TSTDTA]2.0.CO;2

Rauhut, O.W.M., Milner, A.C., Moore-Fay, S. (2010): Cranial osteology and phylogenetic position of the theropod dinosaur Proceratosaurus bradleyi (Woodward, 1910) from the Middle Jurassic of England. Zoological Journal of the Linnean Society, 158: 155-195.

Russell, D.A. (1993): The role of Central Asia in dinosaurian biogeography. Canadian Journal of Earth Sciences, 30: 20022012. http://dx.doi.org/10.1139/e93-176

Sadleir, R., Barrett, P.M., Poweel, H.P. (2008): The anatomy and systematics of Eustreptospondylus oxoniensis, a theropod dinosaur from the Middle Jurassic of Oxfordshire, England. Monograph of the Palaeontographical Society, 160(627): 1-82.

Sereno, P.C. (2000): The fossil record, systematics and evolution of pachycephalosaurs and ceratopsians from Asia. In: M.J. Benton, M.A. Shishkin, D.M. Unwin, E.N. Kurochkin (ed.), The Age of Dinosaurs in Russia and Mongolia. Cambridge University Press, Cambridge, 480-516.

Sereno, P.C., Martinez, R.N., Wilson, J.A., Varricchio, D.J., Alcober, O.A., Larsson, H.C.E. (2008): Evidence for avian intrathoracic air sacs in a new predatory dinosaur from Argentina. PLoS One, 3: e3303.

Sereno, P.C., Tan, L., Brusatte, S.L., Kriegstein, H.J., Zhao, X.J., and Cloward, K. (2009): Tyrannosaurid skeletal design first evolved at small body size. Science, 326: 418-422. http:// dx.doi.org/10.1126/science. 1177428

Smith, A.G., Smith, D.G., Funnell, B.M. (1994): Atlas of Mesozoic and Cenozoic

Smith, N.D., Makovicky, P.J., Hammer, W.R., Currie, P.J. (2007): Osteology of Cryolophosaurus ellioti (Dinosauria: Theropoda) from the Early Jurassic of Antarctica and implications for early theropod evolution. Zoological Journal of the Linnean Society, 151: 377-421. http://dx.doi.org/10.1111/j.1096$\underline{3642.2007 .00325 . \mathrm{x}}$

Turner, A.H., Pol, D., Clarke, J.A., Erickson, G.M., Norell, M.A. (2007): A basal dromaeosaurid and size evolution preceding avian flight. Science, 317: 1378-1381. http://dx.doi.org/10.1126/ science. 1144066

Turner, A.H., Smith, N.D., Callery, J.A. (2009): Gauging the effects of sampling failure in biogeographical analysis. Journal of Biogeography, 36: 612-625. http://dx.doi.org/10.1111/j.13652699.2008.02020.x

Upchurch, P. (1995): The evolutionary history of the sauropod dinosaurs. Philosophical Transactions of the Royal Society of London Series B, 349: 365-390. http://dx.doi.org/10.1098/ $\underline{\text { rstb. } 1995.0125}$

Upchurch, P., Hunn, C.A., Norman, D.B. (2002): An analysis of dinosaurian biogeography: evidence for the existence of vicariance and dispersal patterns caused by geological events. Proceedings of the Royal Society Series B, 269: 613-621. http:// dx.doi.org/10.1098/rspb.2001.1921 
Valkenburgh, B., Molnar, R.E. (2002): Dinosaurian and mammalian predators compared. Paleobiology, 28: 527-543.

Van Itterbeeck, J., Horne, D.J., Bulynck, P., Vandenberghe, N. (2005): Stratigraphy and palaeoenvironment of the dinosaurbearing Upper Cretaceous Iren Dabasu Formation, Inner Mongolia, People's Republic of China. Cretaceous Research, 26: 699-725.

Varricchio, D.J., Sereno, P.C., Zhao, X., Tan, L., Wilson, J.A., Lyon, G.H. (2008): Mud-trapped herd captures evidence of distinctive dinosaur sociality. Acta Palaeontologica Polonica, 53: 567-578. http://dx.doi.org/10.4202/app.2008.0402

Walker, J.D., Geissman, J.W. (2009): 2009 GSA Geologic Time Scale. GSA Today, April/May 2009: 60-61. http://dx.doi. org/10.1130/1052-5173-19.4-5.60

Weishampel, D.B., Barrett, P.M., Coria, R.A., Le Loeuff, J., Xu, X., Zhao, X., Sahni, A., Gomani, E., Noto, C.R. (2004): Dinosaur Distribution. In: D.B. Weishampel, P. Dodson, P., H. Osmólska (ed.), The Dinosauria, $2^{\text {nd }}$ edn. University of California Press, Berkeley, 517-606.

Welles, S.P. (1984): Dilophosaurus wetherilli (Dinosauria, Theropoda) osteology and comparisons. Palaeontographical Abteilung A Palaeozoologie-Stratigraphie, 185: 85-180.

Wu, X.-C., Currie, P.J., Dong, Z.-M., Pan, S., Wang, T. (2009): A new theropod dinosaur from the Middle Jurassic of Lufeng, Yunnan, China. Acta Geologica Sinica, 83: 9-24. http://dx.doi. org/10.1111/j.1755-6724.2009.00002.X

Xu, X., Zhou, Z., Wang, X., Kuang, X., Zhang, F., Du, X. (2003): Four-winged dinosaurs from China. Nature, 421: 335-340. http://dx.doi.org/10.1038/nature01342

Xu, X., Norell, M.A., Kuang, X., Wang, X., Zhao, Q., Jia, C. (2004): Basal tyrannosauroids from China and evidence for protofeathers in tyrannosauroids. Nature, 431: 680-684. http:// dx.doi.org/10.1038/nature02855

$\mathrm{Xu}, \mathrm{X}$., Norell, M.A. (2006): Non-avian dinosaur fossils from the Lower Cretaceous Jehol Group of western Liaoning, China. Geological Journal, 41: 419-437.

Xu, X., Clark, J.M., Forster, C.A., Norell, M.A., Erickson, G.M., Eberth, D.A., Jia, C., Zhao, Q. (2006): A basal tyrannosauroid dinosaur from the Late Jurassic of China. Nature, 439: 715-718. http://dx.doi.org/10.1038/nature04511

Xu, X., Tan, Q., Wang, J., Zhao, X., Lin, T. (2007): A gigantic birdlike dinosaur from the Late Cretaceous of China. Nature, 447: 844-847. http://dx.doi.org/10.1038/nature05849

$\mathrm{Xu}, \mathrm{X}$., Clark, J.M. (2008): The presence of a gigantic theropod in the Jurassic Shishugou Formation, Junggar Basin, western China. Vertebrata PalAsiatica, 46: 158-160.

Xu, X., Clark, J.M., Mo, J., Choiniere, J., Forster, C.A., Erickson, G.M., Hone, D.W.E., Sullivan, C., Eberth, D.A., Nesbitt, S., Zhao, Q., Hernandez, R., Jia, C.-K., Han, F.-L., Guo, Y. (2009a): A Jurassic ceratosaur from China helps clarify avian digital homologies. Nature, 459: 940-944. http://dx.doi.org/10.1038/ $\underline{\text { nature } 08124}$
Xu, X., Qi, Z., Norell, M., Sullivan, C., Hone, D., Erickson, G., Wang, X.-L., Han, F.-L., Guo, Y. (2009b): A new feathered maniraptoran dinosaur fossil that fills a morphological gap in avian origin. Chinese Science Bulletin, 54: 430-435. http:// dx.doi.org/10.1007/s11434-009-0009-6

Xu, X., Zhang, F.C. (2005): A new maniraptoran with long metatarsalian feathers from China. Naturwissenschaften, 92: 173177 http://dx.doi.org/10.1007/s00114-004-0604-y

Xu, X., Zheng, X., You, H. (2009b): A new feather type in a nonavian theropod and the early evolution of feathers. Proceedings of the National Academy of Sciences (USA), 106: 832-834. http://dx.doi.org/10.1073/pnas.0810055106

Young, C.C. (1942): Fossil vertebrates from Kuangyuan, N. Szechuan, China. Bulletin of the Geological Society of China, 22: 293-309. http://dx.doi.org/10.1111/j.1755-6724.1942. mp223-4016.x

Zanno, L.E., Gillette, D.D., Albright, L.B., Titus, A.L. (2009): A new North American therizinosaurid and the role of herbivory in 'predatory' dinosaur evolution. Proceedings of the Royal Society Series B, 276: 3505-3511. http://dx.doi.org/10.1098/ rspb.2009.1029

Zhang, K.J. (1999): Cretaceous palaeogeography of Tibet and adjacent areas (China): tectonic implications. Cretaceous Research, 21: 23-33. http://dx.doi.org/10.1006/cres.2000.0199

Zhang, F.C., Zhou, Z.H., Xu, X., Wang, X.L., Sullivan, C. (2008): A bizarre Jurassic maniraptoran from China with elongate ribbon-like feathers. Nature, 455: 1105-1108 http://dx.doi. org/10.1038/npre.2008.2326.1

Zhao, Q., Xu, X., Jia, C., Dong, Z. (2008): Order Saurischia. In: J. Li, X. Wu, F. Zhang (ed.), The Chinese Fossil Reptiles and their Kin. Science Press, Beijing, 279-335.

Zhao, X.-J. (1983): Phylogeny and evolutionary stages of Dinosauria. Acta Palaeontologica Polonica, 28: 295-306.

Zhao, X.-J., Benson, R.B.J., Brusatte, S.L., Currie P.J. (2010): The postcranial skeleton of Monolophosaurus jiangi (Dinosauria: Theropoda) from the Middle Jurassic of Xinjiang, China, and a review of Middle Jurassic Chinese theropods. Geological Magazine, 147: 13-27.

Zhao, X.-J., Currie, P.J. (1994): A large crested theropod from the Jurassic of Xinjiang, People's Republic of China. Canadian Journal of Earth Sciences, 30: 2027-2036. http://dx.doi. org/10.1139/e93-178

Zheng, X.-T., You, H.-L., Xu, X., Dong, Z.-M. (2009): An Early Cretaceous heterodontosaurid dinosaur with filamentous integumentary structures. Nature, 458: 333-336. http://dx.doi. org/10.1038/nature07856

Zhou, Z., Barrett, P.M., Hilton, J. (2003): An exceptionally preserved Lower Cretaceous ecosystem. Nature, 421: 807-814. http://dx.doi.org/10.1038/nature01420 